\title{
JUAN FERNANDEZ AND HAWAII
}

A PHY'TOCHOGRAPHICAL, DISCUSSION

BI

C. SKOTTSBERG

BzRNice P. BISHOP MUSRUM

BLLIETIN 16

JotowUL, KAWARI

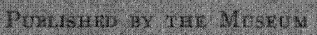

1025 


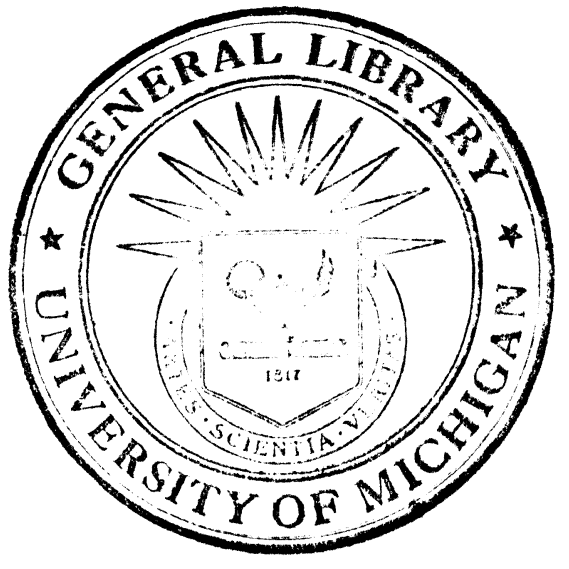


H 


\section{JUAN FERNANDEZ AND HAWAII}

A PHYTOGEOGRAPHICAL, DISCUSSION

BY

C. SKOTTSBERG

Bernice P. Bishop Museum

Bulletin 16

HONOLULU, HAWAII

Published by the Museum

1925 
Professor Carl SkotTsberg, Director of the Botanical Garden at Gothenburg, Sweden, was Bishop Museum Fellow in Yale UNIVERSITY FOR THE YEAR 1922-23. JUAN FERNANDEZ AND HawaII IS THE FIRST OF A SERIES OF PAPERS RESULTING FROM A STUDY OF PACIFIC FLORAS. 


\section{Juan Fernandez and Hawaii}

A PHYTOGEOGRAPHICAL DISCUSSION

By CARL SKotTSBERG

\section{INTRODUCTION.}

My brief visit to the Juan Fernandez islands in 1908 ultimately led to a detailed study of these remarkable islands in 1916-17, and definitely turned my interests toward questions of general bearing on the past and present distribution of insular species of plants in the Pacific. I soon found it impracticable to limit my studies to those little islands, as no attempt to solve their enigma ought to be made without a more extended knowledge of other Pacific islands with a richer and more varied flora. No place seemed better suited for my purpose than the Hawaiian Islands where, thanks to the efforts of Asa Gray, Mann, Wawra, Hillebrand, Rock and others, the vascular plants are fairly well known. Unfortunately I was forced to decline an invitation to attend the Pacific Scientific Conference, held in Honolulu in 1920 and therefore the more eagerly accepted an election as a Bishop Museum Fellow in Yale University in 1922. The means thus made available, supplemented by the financial support of a number of personal friends in Sweden, enabled me to undertake the journey.

I arrived in Honolulu on August I and left on November 8, 1922. From the time of my arrival I was given the facilities of the Bishop Museum, as well as of the experimental stations of the Hawaiian Sugar Planters' Association and the Bureau of Forestry. If, among friends and promoters, I mention only Herbert E. Gregory, A. F. Judd, C. M. Cooke Jr., H. L. Lyon, and E. L. Caum, this does not signify that the others are forgotten; but only that they are too many to be enumerated. The islands of Oahu, Hawaii, Maui and Kauai were visited. Wherever I went, I was most liberally assisted by the residents, who did all in their power in a most unselfish manner to insure success. My indebtedness is great to all of them. Should my humble studies offer a contribution, however slight, toward an extended knowledge of their wonderful islands, I shall experience a deep satisfaction.

It is too early to say anything about the final results of my Hawaiian tour. Its object was to make me familiar with the composition of the 
fora, to collect material for future studies, and to test my theories of the history of Juan Fernandez. The present paper should be taken for what it is-a discussion on troublesome problems. It will meet with much opposition, but I hope that at least some of my ideas are worth considering and not altogether unsound.

The manuscript of this publication was submitted for criticism to Forest B. H. Brown, botanist on the staff of the Bishop Museum. His comments, without alteration, have been inserted in their appropriate places. To each of the comments I have added a short remark. I thank Dr. Brown for the interest thus shown, but I fear that the divergencies in our views are too fundamental to be bridged by discussion. His "PanAmerican" views on the origin not only of Hawaiian but even of IndoMalayan and Australian plant life are too revolutionary to pass without criticism.

\section{FLORISTIC RELATIONS BETWEEN JUAN FERNANDEZ AND HAWAII}

In $1920 \mathrm{Mr}$. W. A. Bryan, author of natural history books dealing with Hawaii, visited Juan Fernandez where he looked for support of the theory of a large sunken Pacific continent. He states (6) ${ }^{1}$ : "Many of the endemic species are very similar to those found here [in Hawaii] under similar conditions." While in Chile, Mr. Bryan used more positive expressions. According to an article in the Chilean newspaper "E1 Mercurio," he regarded the general character of the flora and fauna of Juan Fernandez and Hawaii as almost identical, which proved that they had once been closely united. In a lecture before the Philadelphia Academy of Natural Science -unfortunately I know this only from an abstract (3Oa)-he based his idea of a continent uniting South America with Hawaii on the discovery in Juan Fernandez of land-shells very like the Hawaiian ones-a discovery which lead him to undertake a second visit. His communications to the Honolulu Conference were made after his return from this second trip.

In the paper quoted (6) there are indications that Bryan's studies have not been of a very profound nature, at least as regards vegetable life. Thus he tells us that on the island of Mas-a-fuera "the flora extends in almost every case from the shore to the very summit," contrary to the conditions in Hawaii, and that "it was a singular and significant thing to note the wide range of plants which inhabit that island." This statement is erroneous. In Mas-a-fuera there is the same marked areal distribution as in Hawaii, in conformity with climatic regions. Bryan's statement also that the marine animals probably with the exception of the large lobster (Jasus lalandei)

\footnotetext{
${ }^{1}$ Figures in parenthesis refer to the bibliography, pp. 46, 47.
} 
are all of South American origin, needs revision. On the other hand, it seems that Bryan has greatly overestimated eventual points of resemblance. If the supposed affinity is to be discussed in earnest, it is better to forget general likenesses and keep to actual examples. Such examples are few. In this paper I shall confine myself to the flowering plants.

There are 142 species of flowering plants indigenous to Juan Fernandez (26) ; about 9oo, to Hawaii. The figure for Hawaii is an estimate, for numerous monographs are needed before the exact number can be ascertained. The following species are reported to occur in both groups:

Peperomia fernandeziana Miq. Described from Juan Fernandez, also found in Chile. Attributed to Hawaii by De Candolle (8); also quoted by Hillebrand and De Candolle (9). The species' has not been found again in Hawaii. Its occurrence there is very doubtful.

Nertera depressa Banks. Widely distributed along the Pacific coast of South America, ranging as far north as Mexico and known to occur in a few Subantarctic islands, in Australia, Tasmania, New Zealand, the Society Islands, and Malaya, thus showing a circumpolar distribution. This species is therefore of little use as evidence of connection between the American continent and Hawaii.

Fragaria chilensis Ehrh. Reported from the west coast of America from Alaska to Chile, but with many breaks in its distribution. Probably not truly indigenous in Juan Fernandez. Also of the plants belonging to this species, those collected by me in Hawaii differ in some respects from my South American material.

Specific identification of forms common to Hawaii and South America is limited to these three forms. No conclusions can be drawn from so few, even dubious, comparisons. My study of related, perhaps vicarious, species of the two regions which according to Bryan obviously give the floras a marked degree of affinity has led to the following results:

Cladium scirpoideum Benth. \& Hook. Endemic in Mas-a-tierra and not of American affinity; but is clearly near the Hawaiian $C$. angustifolium Drake.

Peperomia. Four species in Juan Fernandez and many in Hawaii (9). Probably related to each other and belong to an important Polynesian group. The Juan Fernandez species are not closely allied to the tropical American species, as I was informed by De Candolle (25).

Santalum fernandezianum F. Phil. Now apparently extinct. Has no relatives in America, where the genus is missing, but is near some Hawaiian and western Pacific species.

Chenopodium. In Juan Fernandez, three dwarf arboreous species. Appear to have their nearest relative in the Hawaiian Ch. sandwicheum Moq.

Ranunculus caprarum Skottsb. from Mas-a-fuera. Is not allied to American species but approaches two New Zealand species and also $R$. hawaiiensis A. Gray.

Sophora fernandeziana and $S$. masafuerana $R$. A. Phil. Close to the species of Chile and New Zealand, also distinctly allied to S. chrysophylla Seem. of Hawaii.

Gunnera. The three species in Juan Fernandez seem to come nearer to the Hawaiian than to the Andine forms.

Plantago fernandezia Bert. (arboreous). Is very remote from the numerous American species and has but one near relative, $P$. princeps Cham. of Hawaii.

Coprosma. A genus richly developed in New Zealand and Hawaii and represented in other Pacific islands, is absent from America but has two species in Juan 
Fernandez. The exact systematic position of the Juan Fernandez forms in relation to the Hawaiian species remains to be determined.

Erigeron. The five Fernandezian species are remarkably removed from the many Andine ones and have been reported to come near the Hawaiian genus' Tetramolopium, but further investigation is necessary.

Finally, the Senecioid genera Robinsonia and Rhetinodendron bear a certain resemblance to Dubautia and Raillardia, but a decisive opinion on this supposed relationship must await further study.

The meagerness of this list is to be regretted, particularly when it is remembered that a great number of types like Cuminia, Dendroseris, Centaurodendron, arboreous Eryngia, Selkirkia, or Lactoris do not correspond to any forms in Hawaii, and that most Hawaiian genera-for example, the Lobelioideae-have no relatives at all in Juan Fernandez. For nearly all species, no direct relation is obvious and I feel no temptation to build a bridge from Hawaii to Juan Fernandez, or to imagine that these island groups are fragments of one old continent. But it is a satisfaction to see that several notable plants from these islands, although separated from each other by an enormous distance, belong to the same Pacific circle of affinity. Another circumstance, to which I am inclined to attribute some weight, is the existence in both regions of non-American elements, which, to be candid, involve no systematic affinity, but which show certain common features in their morphology, occurrence, and distribution in each island group and suggest that they belong to an ancient Antarctic and south Pacific flora, now broken up and scattered.

\section{FLORAL ELEMENTS IN JUAN FERNANDEZ AND HAWAII}

Of the 142 species in Juan Fernandez, 43 per cent are of the Andine type or even identical with south Chilean species; 39 per cent show little or no American affinity and are systematically isolated, or have (a few of them) an Hawaiian affinity-I have called these Old-Pacific (25) because the numerous independent types, belonging to many families, suggest that this flora has existed in the Pacific for ages; I3 per cent have distinct relations with New Zealand and Polynesia; 13 per cent form a MagellanicSubantarctic group-nearly all found on the island of Mas-a-fuera, as life-conditions in the lower island of Mas-a-tierra are not suitable; 2 per cent are widespread. Of the ten endemic genera, four belong to the Andine and six to the Pacific group.

Of the Hawaiian phanerogams, 32.3 per cent are Old-Pacific; 29 per cent, Australian-Polynesian; 26.5 per cent, Indo-Malayan; 7.5 per cent, American; 3.3 per cent, widespread; I.2 per cent Subantarctic; and 0.2 per cent Boreal. I want to emphasize that these figures are provisional and may undergo some change. It is impossible to arrive at definite results at present. 
I have included the Hawaiian Lobelioideae among the old-Pacific types. The categorical assertion that nearly all of these are of American origin is ill-founded; some of them certainly are not, and Hawaii is at present a predominant center of this subfamily, which is more richly developed here than elsewhere. The direct derivation from the American genera Centropogon and Siphocampylos seems indeed questionable. To the same group I refer the Hawaiian species of widespread genera like Viola, Geranium, or Lepidium; they are simply called "boreal" by some students familiar with their boreal representatives, but for no valid reason. For example, the Hawaiian species of Geranium form a special section which according to Knuth (2I), is one of the most distinct within the whole genus, the relations of which to the other sections (there are 30 of them) are quite obscure. Likewise the Hawaiian species of Lepidium belongs to a considerable Australian-Pacific group, as shown by the excellent monograph of Thellung (28). Unless this section is polyphyletic, so that the species in each district have been derived from separate boreal species, which is, of course, highly improbable, it must have had a long history in and around the Pacific. I believe that the sadly needed revision of the genus Viola will yield the same result.

The Australian-Polynesian and Indo-Malayan groups of plants are sometimes difficult to separate; there are species that might reasonably be considered in either group. A few types which should, perhaps, form a special East Asiatic group are included among the Indo-Malayan species. The American group has been treated liberally and probably contains doubtful members, still it is very small compared with the Pacific and western groups. The Subantarctic group contains species clearly connected with the circumpolar Subantarctic flora, believed to have its original or secondary home in the Antarctic continent. The boreal group includes two species, the Drosera longifolia L. and the Carex macloviana Lam., which occurs also in South America and elsewhere.

From this brief review the following conclusions are drawn:

(I) There is, both in Juan Fernandez and Hawaii, a strong Pacific element, not directly represented on the neighboring continents, but to some extent in New Zealand and Polynesia; most of these plants are woody, and many belonging to very different families show the peculiar life-form of "rosette-trees," called by Schimper "schopfbäume" (24). All are endemic and include most of the systematically isolated genera and species. My observations in the field have convinced me that these dwarf trees cannot be interpreted as a late adaptation to an insular, windy climate, as Schimper thought, but that they represent an organization type probably better represented during the Tertiary. This type is not confined 
to islands, or to open, wind-exposed situations where it is, as I have tried to show, of doubtful advantage (25);

(2) Hawaii has a large Indo-Malayan element, lacking in Juan Fernandez ;

(3) Both Hawaii and Juan Fernandez have Australian-Polynesian types, which do not occur in America-a very noteworthy condition in view of the fact that Juan Fernandez is only 360 miles from Chile ;

(4) Both regions have American types, Juan Fernandez proportionally more;

(5). Both regions have Subantarctic species, forming two extreme outposts of the circumpolar flora. As is to be expected, the Hawaiian species are much fewer, especially in proportion (Hawaii, I.2 per cent; Juan Fernandez, I3 per cent). It is surprising that there are any at all. Three genera, Oreobolus, Lagenophora, and Acaena, are represented in both groups, and the Hawaiian Acaena exigua A. Gray is not related to New Zealand species but to the Fuegian A. pumila Vahl; in fact, these two species form a special and well characterized section.

\section{SYSTEMATIC AFFINITY AS AN INDICATOR OF FLORAL HISTORY.}

Opinions differ regarding the relations of the floras of Hawaii and Juan Fernandez with other floras. For Juan Fernandez, where the systematic position of phanerogams is fairly well known, the ferns strengthen my conclusions. Regarding Hawaii, there appears to be considerable diver gence of opinion.

H. B. Guppy, whose experience with Pacific vegetation is extensive, advances the view (I4) that the endemic genera in Hawaii are the oldest. These "Pacific endemic genera," represented especially among the Lobelioideae and Compositae, are said to be nearest to American genera and to have been dispersed during the early Tertiary, the "Age of Compositae" (is not the present era more entitled to this name?) mainly through the agency of birds. The remaining endemic genera Guppy divides into two groups, an older American (longer from the old world) and a younger. Eastern Polynesia and Hawaii did not get their share of the Mesozoic Polynesian flora, because these islands had not emerged at that time. Thus the Polynesian element must be younger, though still including endemic genera. Lastly, the Indo-Malayan plants arrived, aided by winds, currents, and fruit eating birds-in postglacial time.

This is a surprising conclusion, for among the Indo-Malayan species are numerous endemics, a fact out of accord with existing knowledge of the character of postglacial floras in other parts of the world. Guppy overrates the influence of the Ice Age in Hawaii. Recent investigations 
on Mauna Kea, especially by Herbert E. Gregory (I3), have disclosed undisputable evidence of glaciation, also noted by me. Gregory thinks that a minor displacement of plant regions may have followed as the result of an Alpine ice-cap. There can be no question, as far as my experience goes, that no changes took place sufficient to produce new species or varieties of most plants that arrived during this time, according to the old belief in species-making following a change in conditions. (See also p. 23.) Guppy assumes that during the glacial period the Subantarctic species-or rather their ancestors, for they are endemic-took a jump to Hawaii. The statement of the problem is complicated for Guppy believes in non-contemporaneous glacial periods on the northern and southern hemispheres, a theory abandoned by nearly all geologists of our days.

According to Guppy, the Polynesian flora performed its wanderings in an easterly direction by means of interposed islands, Hawaii being the terminus. The flora battled its way against unfavorable winds and currents, strongly assisted by the activity of birds. It never reached the new world. Apparently Guppy is unaware of the fact that such forms live on Juan Fernandez, close to South America. I admit that winds and currents are more favorable here: but one might ask why were not the same "ancestors" carried to the continent as to the islands? Guppy's ideas were severely criticized by Campbell (7). He finds it more likely that the Compositae belong to a younger element and that their endemic genera may be American. For the Lobelioids he denies any sound reason for their derivation from America and doubts the introduction of the Indo-Malayan element with fruit eating birds. Of course Guppy very well knew the peculiar character of the Hawaiian Ornis, which he derives from a few early immigrants not followed by later arrivals. Obviously he contradicts himself here, for how did transportation by birds on a sufficiently large scale take place in postglacial time if the Hawaiian bird fauna at the same time remained utterly isolated?

Campbell believes in a more or less direct land connection with an hypothetical continental area to the southwest of Hawaii. He finds that the faunistic relations also speak in favor of this theory.

Forest B. H. Brown has summarized his opinion on the origin of the Hawaiian flora (5). He considers that the 780 dictyledons have heen derived from 125 ancestors, establishing this figure on the assumption that each well characterized genus has one ancestor that developed all its species in Hawaii. Perhaps this simplifies matters a little too much. There is little positive knowledge of the phylogeny of Hawaiian dicotyledons, and because a genus is endemic it is not necessarily locally mono- 
phyletic. ${ }^{2}$ Brown distinguishes between two "dispersal waves," both coming from the region of Central America during an epoch when there was open connection between the oceans still washing its shores, and Atlantic currents entering the Pacific. The first is assigned to JurassicComanche time. But this is a period in the earth's history so remote that all the fossil remains known are insufficient to give a clue to the origin of the present Hawaiian flora. Very likely many of the families mentioned by Brown had not yet appeared and I am afraid it is impracticable altogether to establish relations between those and Jurassic plants. I believe geologists agree on the young age of Hawaiian rocks; certainly the present rocks do not date back to Jurassic times. Consequently it may be asked: was there a Jurassic Hawaii, and if so what was it like?

Of course there are no facts on which to base an answer, but if there was land in the region where later the volcanic masses of today's Hawaii burst forth, can it not be as well imagined that the land mass was large, close to or part of other Jurassic lands, having a Jurassic vegetation? From the actual composition of the Hawaiian flora it cannot be concluded that in Jurassic time Hawaii started a lifeless oceanic island which received "ancestors" from America or other distant regions. According to Brown the first wave was entirely American. But even if the hypothetical connection with Jurassic floras be left out of consideration, the American affinity of the Hawaiian representatives of most of the 16 families mentioned by Brown is perhaps doubtful.

${ }^{2}$ Comment by Brown: It is neither stated nor implied by me that the number of immigrants bears any constant relation to the number of genera; on the contrary, an examination of the table (3, p. I35) clearly shows the absence of any such relation. However, a closely related series of species, such as we find in Schiedea-Alsinidendron, may reasonably be regarded as a phyletic branch arising from a single antecedent. The essential integrity of each endemic series hardly encourages the supposition that the Hawaii of the past has ever been of continental size, or connected, or close to large land areas. This, however, does not exclude the supposition that constant changes have occurred as a result of which one or more islands of the chain have been united into one, and conversely.

Comment by SKo'TrSBERG: The number of ancestral immigrants in the table accords, with few exceptions, with the number of peculiar endemic genera in each family. The exceptions are the following: Caryophyllaceae and Malvaceae with one ancestor and two endemic genera, respectively; Labiatae with one ancestor and three genera; Campanulaceae with three ancestors and six genera. If Tetramolopium is kept separate from Erigeron, the sp. Compositae have seven ancestors' and eight endemic genera, but to judge from the number of descendants in the table, Brown also includes Lipochaeta among the Erigeron. The table shows that, for most plants, one immigrant has produced one genus, but that, for some of them, two or three nearly related genera are supposed to have the same ancestor. The "essential integrity of each endemic series" spoken of by Brown bears witness of progressive endemism under long isolation, but taken by itself tells very little about the earlier floral history of the country. We meet with the same problem in continental areas, as Western Australia, Cape Colony and the highlands of Mexico. 
There is no good reason to regard either the Hawaiian Urticaceae ${ }^{3}$ (Touchardia, Neraudia) or Caryophyllaceae 4 (Alsinidendron, Schiedea) as American; the Amaranthaceae ${ }^{5}$ (Charpentiera, Notothrichium) are probably not from the New World. Broussaisia ${ }^{6}$ is a member of a mainly

3 Comment by Brown: The Boehmerieae have a concentration of species and genera in the Isthmian region of America, from which center the Hawaiian representatives may have been derived, as well as perhaps related species forming a second concentration in the region of the East Indies.

Comment by Skot'TSBERG: Of the I8 genera of Boehmerioideae the largest two, Boehmeria and Pouzolzia, are divided between the Old World and the New World, two are exclusively American, and the remaining fourteen are distributed over Eastern Asia, Indo-Malaya, Polynesia and Australia. The Hawaiian genera belong to a decidedly Indo-Malayan-Polynesian group. The greatest concentration of genera, twelve in number, is in East India and the Sunda Islands, certainly not in America, and from the available data I do not find that there is any marked concentration of species of the American genera in the Isthmian region unless we allow this to extend from Mexico to Brazil.

${ }^{4}$ Comment by Brown: The Alsineae center in the Mediterranean region, but have a second concentration in the Isthmian American region. They are poorly represented in the Malay region and Australia. The Hawaiian representatives may have been derived directly from Isthmian America, or indirectly from the Mediterranean region, through the Isthmian Strait.

Comment by Skotrsberg: In the Alsineae are several more or less world-wide genera like Stellaria, Cerastium, Minuartia, Sagina, Arenaria and Moehringia, but all of these are, at the same time, eminently boreal. There are some Mediterranean genera, as Holosteum, Moenchia, Buffonia, but they become more developed eastward, and the generic concentration is Asiatic-Asia Minor to Himalaya and Thibet-not Mediterranean. No more may be said at present of Schiedea and Alsinidendron than that they are peculiar Pecific genera. There are other Alsinoid genera (circumpolarsubantarctic and Andine), with a wholly obscure past, as Colobanthus, which according to Drake and Castillo (ro), is allied to the Hawaiian genera. If these genera could be connected with Mediterranean ones, such a derivation might be considered; but as it is, there is' no clue to their origin. The "second concentration" of the Alsineae in Isthmian America is not recognized by other authors.

5 Comment by Brown: Approximately one-half of the Amaranthinae are American, from which source the Hawaiian representatives may have originated. The Achyranthinae, however, center in Africa, but have a westward extension into Isthmian America. The distribution favors the conclusion that, particularly with land connections' between Africa and America, the Hawaiian representatives may have originated directly or indirectly from America.

Comment by Sкот'TSBERG: Of the Amaranthine genera, ten in number, Amaranthus is cosmopolitan, three are American, and six Old World. Charpentiera is related to Bosia (Cyprus, India, Canary Islands): this statement will probably lead Brown to put it in a clas's with his Prasium-derivatives (p. 14); but, unfortunately, the affinity is with the Indian species, which has been regarded as constituting a separate genus by Bentham and Hooker. The "extension" of the Achyranthinae into the Isthmian region seems to be based upon the occurrence of a few species of Achyranthes in Central America and South America, and has no value for this discussion. Notothrichium shows very distinct Old World and Australian relations, nothing else.

${ }^{6}$ Comment by Brown: The Hydrangeae extend northeast into North America, and southward along the mountains into South America, and Broussaisia seems more closely allied to the American representatives, than to the Asiatic.

Comment by SKot'TSBERG: What is said here about the extension of the Hydrangeae into America holds good only for Hydrangea and Decumaria, the other eight genera are Asiatic save for Broussaisia. As this genus is allied to Dichroa, mono- 
Asiatic group and not related to American genera. Of the Rutaceae, Pelea and probably Platydesma ${ }^{7}$ are not of American affinity. To say anything definite about Kokia or Hibiscadelphus is not possible at present; the related genera Gossypium and Hibiscus are pan-tropical. Regarding Isodendrion (Violaceae) the American affinity seems well established. The peculiar Hillebrandia is of special interest. ${ }^{8}$ Probably it is the most primitive of Begoniaceae; even if the genus Begonia luxuriates in tropical America, there is of course no reason to derive Hillebrandia from that part of the world. It is an old relict type, and no trace of fossil members of the family give clue to its earlier history or distribution. The Hawaiian endemic araliaceous genera are of exclusively Indo-Malayan affinity. ${ }^{9}$

typic (Himalaya to Philippine Islands') and not to the genera with American species, I cannot understand Brown's' comment.

7 Comment by Brown: The distribution of the Xanthoxyleae is similar to that of many other groups having representatives in Hawaii, namely a concentration in Isthmian America, and a westward extension over the Pacific to South-east Asia, and Australia. It is probable that the Hawaiian representatives, Pelea and Platydesma, as well as the close relatives in the region of Australia, are American derivatives.

Comment by SKo'T'SBERG: Looking for proofs of the "Isthmian concentration" in this case, we find the following facts: Of the Evodiinae, to which Pelea belongs, Xanthoxylum occurs in Eastern Asia and in North America, Fagara is pan-tropical, all the other genera, thirteen in number, non-American; six are endemic in Australia, two in New Caledonia, one in Japan, one in the Bonin Islands, one in Madagascar. Evodia and Melicope center definitely in Australia and do not occur in America. The Lunasiinae include only Lunasia (Indo-Malayan); the Decatropinae, three small Mexican genera; the Choysinae, of which Platydesma is a member, five more genera: one in Australia, one in New Caledonia, two in Mexico (one extending into Arizona). All seem to be mono-typical. Finally, the group Pitaviinae consists of only one monotypical Chilean genus. There can be no question of any concentration of Xanthoxyleae in Isthmian America. Pelea shows undisputable Australian affinity, of Platydesma I can only say that there is no reason to call it an American derivative. To quote the best authority on Rutaceae, A. Engler (I2): Xanthoxyleae is the group nearest to the hypothetical primitive Rutaceae, it has attained the widest distribution, it centers in Australia and the Western Pacific.

8 Comment by Brown: The Begoniaceae center primarily in or near Isthmian America, but this group is closely connected with a secondary concentration in the region of the East Indies, which may be regarded as a derivative of the American group, and may have arisen from very few antecedents. The distribution of the genera and species indicates that the Begoniaceae have spread westward over the Pacific, from the American center.

Comment by SKot'TSBERG: The statement that "Begoniaceae has spread westward over the Pacific" is indeed questionable. The only large genus, Begonia, is absent from Polynesia from Fiji to Galapagos, and thus has left no trace of the supposed trans-Pacific migration. Hillebrandia is more primitive than Begonia and not an offspring from some travelling species of that genus. The sections in Asia, Africa and elsewhere are systematically well defined, and there is no reason to say that these Begonia-floras are mere branches of the American.

9 Comment by Brown: Hardly "exclusively," even in close affinities, Madagascar, Africa, and America must be included.

Comment by SkơTSBERG: I think I have expressed myself correctly: (See also Drake del Castillo, ro.) The non-endemic Tetraplasandra has one species outside Hawaii (New Guinea): the Polynesian Reynoldsia is near this genus. Cheirodendron is very near Nothopanax, not in America but best represented in New Zealand. Pterotropia shows relations with Reynoldsia and with the Asiatic species of 
Labordia (Loganiaceae) forms with Geniostoma a decidedly non-American group. ${ }^{10}$

Pteralyxia (Apocynaceae) is considered nearest to Alyxia, a genus not occurring in America. ${ }^{11}$ A particularly instructive example is furnished by the Labiatae: Haplostachys, Phyllostegia and Stenogyne, belonging to the tribe Prasieae, which has not a single American representative. Brown calls them "indirectly American," because there exists, in the Mediterranean region, the mono-typical Prasium majus L., and from there the ancestors of Hawaiian genera are believed to have travelled across the Atlantic, through the Isthmian Strait to Hawaii. If a source is to be assigned, why not look toward Asia, where the rest of the tribe lives? Keeping to bare facts, do we really know more than that the Prasieae must be an old tribe, as it occupies a broken area and has no near relatives, and that $P$. majus has a somewhat isolated position in the present Mediterranean flora? Its geological history is unknown. I am inclined to pay some attention to people who have a good knowledge of the family, such as Briquet, who states (3, p. 203) that the Prasioideae are IndianOceanic with one Mediterranean representative, a westerly member of the group, and further that the Hawaiian genera are undoubtedly connected

Schefflera (I5). The genera of Araliaceae are, in several instances, badly defined, but even with our present knowledge we can safely say that the Hawaiian genera and species point toward the Old World, not toward the New World center of the family.

10 Comment by Brown: The family and the tribe to which these genera belong center definitely in America.

Comment by Skot'TsBeRG: A new critical treatment of the system of the Loganiaceae by Klett (20) has just appeared. Space does not permit me to quote it at any length, but the following remarks' throw sufficient light on Brown's statements. The tribe Loganieae comprises two subtribes, Geniostominae and Loganinae, apparently natural groups. The Geniostminae includes only two nearly allied genera, Geniostoma (70 species, Australia, Polynesia, Malesia), and the Hawaiian Labordia. These genera occupy an independent position: "Die beiden Gattungen direkt an eine der bei den Loganiaceen bestehenden Gattungsgruppen anzuschliessen ist nicht möglich" (p. 323). This statement is quite as important as that made by Brown, more so as Brown's statement is incorrect. The Loganinae include nineteen genera, seven of which are exclusively American, one found also in Asia, one (Buddleia, the largest), also in Asia and Africa; seven are African or Malegassic, two Australian, one Malayan. There is no reason to say that "this tribe centers definitely in America." And if we take the other tribe of the same subfamily, Gelsemieae, one genus is American and Asiatic, one exclusively African, one African with two American species. Let us extend our examination to the second subfamily, Strychnoideae. Klett enumerates nine genera: two, both monotypical, are American, Strychnos is well represented in both Asia and America, but appears to have its main center in Africa, two are only African, four are Indo-Malayan or also Polynesian. The family is not decidedly American and America is not necessarily the birth-place of Labordia.

11 Comment by Brown: Both genera, however, are closely related to the American Vallesia, where the group primarily centers.

Comment by SkotTsBERG: The genera in question are also near Hunteria (Asia and Africa). I have not been able to discover the grounds on which Brown's arguments are based. 
with the Indo-Malayan Gomphostemma. If the results of Briquet's studies are to be disregarded, it is necessary to bring forth new facts irreconcilable with his opinion, and this has not been done. ${ }^{12}$

Regarding Nothocestrum (Solanaceae) we have as good reasons for for placing it near Withania (Old World) as near Athenaea ${ }^{13}$ (Brazil). And I decline to share the responsibility of declaring the endemic genera of Rubiaceae as American derivates. ${ }^{14}$ The Lobelioideae have already been mentioned on page 8 . Some of the Compositate, like Remya, Lipochaeta, Campylotheca or Wilkesia-Argyroxiphium, suggest American ancestors, the systematic position of Tetramolopium remains to be settled. DubautiaRaillardia combine characters of several groups, but even if they point toward Raillardella (Californian) among others, no tolerably safe conclusion lies near at hand. It is true that most Mutisieae are American, but there are peculiar small genera in many parts of the world and Hesperomannia cannot be linked together with American genera better than with others.

The second dispersal wave of Brown is said to have arrived during the lower Eocene and to have come, in large part, from the same source

12 Comment by Brown: Inasmuch as Briquet points to no evidence for his conclusion, the reader is left to search for the facts; such evidence as we find certainly cannot be accepted as proof without further explanation. For example, the anthers of the Hawaiian representatives are characterized by divergent thecae-a character recorded in Prasium, but not in Gomphostemma. Similarly, other prominent morphological characters, such as the two-lipped calyx, pedecillate flowers, two-flowered whorls, and fleshy fruits, appear to link the Hawaiian representatives more definitely with Prasium than with Gomphostemma. We have also the statement of Bentham (Ia) who concludes the description of Phyllostegia as follows: ". . . Genus quod fructum Prasio conforme, longe differt in habitu et patria."

Comment by SkotTsBerg: Certainly I do not disclaim the affinity between Prasium and the Hawaiian members of the same tribe. But both types point toward Eastern Asia. Prasium is a westerly outpost, a stranger in the Mediterranean flora, the Hawaiian genera are an eastern extension of the tribe. To call the latter "indirectly American" is impossible.

13 Comment by BRown: The grouping of related genera indicates an American origin, whether we consider Withania, Athenaea, or Acnistus as the genus most closely related to Nothocestrum.

Comment by SkotTSBERG: I can add nothing to what I have said: I only mean that we cannot simply call Nothocestrum American.

14 Comment by Brown: The fact that the four groups to which these genera belong have a common center in Isthmian America, favors the conclusion that the Hawaiian genera of Rubiaceae are not unlikely of American origin.

Comment by SkoTTSBERG: Kadua belongs to the Oldenlandia group, including about 35 genera. Only nine are represented in America. Gouldia belongs to the Mussaenda group, over 40 genera, of which 16 are American or represented there. Bobea belongs to the Guettarda group, a dozen genera, half of these American. Finally, Straussia is a member of the Psychotria group, with more than 30 genera: nine are exclusively American or well represented in America, Brazil being by far the richest country in species. That these four groups, which have the majority of their genera outside America, should have their common center in the Isthmian region is a supposition not supported by facts. 
as the first. To this wave are referred the remaining indigenous plants. Brown states that the ten largest families (nine of which are mentioned by name) found in the Eocene of the lower Mississippi valley are abundantly represented in Hawaii. I should prefer to exclude the word "abundantly" in view of the following evidence regarding distribution:

Lauraceae. World-wide, more than one thousand species, but only two in Hawaii. One species, Cassytha filiformis L., is found in all continents except America; the other, Cryptocarya mannii Hillebr. is endemic, the genus chiefly Australian-Indomalayan. ${ }^{15}$

Urticaceae. The non-endemic genera in Hawaii hardly suggest an American origin.

Leguminosae (including Caesalpiniaceae and Mimosaceae). Worldwide, more than twelve thousand species, nineteen in Hawaii. Several of these are widespread tropical species, some others cannot possibly be connected with America. Of approximately two hundred phyllodine Acacias there is not one in America, and if the Hawaiian species should be traced back to that region on account of a fossil phyllode-like structure in the American Eocene, the conclusion will be that also the other members of the Nervosae, some Australian and one Mascarene species (close to A. koa A. Gray) should have come from the same source, which is absurd. The endemic Cassia belongs to a section not represented in America, Mezoneuron is purely paleotropic, Strongylodon confined to Oceania, Ceylon and Madagascar. ${ }^{\mathbf{1 6}}$

15 Comment by Brown: The families cited, including the Sapotaceae not mentioned, are represented in the younger flora of Hawaii by an average of about three ancestral immigrants each, which is a decidedly high representation in comparison with families in the old group (about two each) or the remaining families of the young group (less than two each). The ratio is about what would be expected with transoceanic migration from a region where these families were as large as in the Isthmian American lower Eocene. Cassytha filiformis L. occurs in the West Indies, and in the tropical parts of the American Continent, as well as in other tropical regions. Cryptocarya is well represented in tropical America, where there is a decided grouping of related genera.

Comments by SkotTSBERG: According to my belief the material at hand does not allow us to discuss the question put forth by Brown. The Cassytha of the Bahamas and West Indies is $C$. americana Nees, also occurring on the continent. I have not sufficient literature at hand to corroborate the statement on $C$. filiformis in America. The genus is chiefly Australian. The decided grouping of genera related to Cryptocarya only means that three genera are American (one of these of doubtful affinity), one East Indian and one from Madagascar: Cryptocarya has its center in Southeastern Asia.

16 Comments by Brown: Even in the distribution of Acacia and related tribes, there are strong indications that the primary center of dispersal occurs in America, and the finding of the fossil phyllode near the American center is quite what one would expect on basis of distribution of living forms, and the probability that the great variation occurred at the center.

Comments by SkotTSBERG: The strong indications' spoken of are unknown to me. 
Rhamnaceae. Widely distributed, about five hundred species, of which seven occur in Hawaii, none of them related to American species. ${ }^{17}$

Sapindaceae. More than one thousand tropical species, six in Hawaii. Among these Alectryon is purely Indomalayan-Polynesian. Fifty out of fifty-two species of Dodonaea are Australian: only one, the pantropical D. viscosa, occurs in America. ${ }^{18}$

Myrtaceae. Metrosideros, remarkably developed in Hawaii, is a decidedly Polynesian genus, absent from America. Syzygium sandvicense A. Gray belongs to a genus well represented in Southeast Asia but without American species. ${ }^{19}$

Anacardiaceae. About five hundred species, with a single one in Hawaii, a variety of Rhus semialata Murr. (Eastern Asia). ${ }^{20}$

17 Comments by Brown: The two tribes to which the Hawaiian representatives belong each have their primary concentration of species and genera in America.

Comments by Skot'TsBerg: Colubrina (chiefly American, one Hawaiian species endemic, one paleo-tropic) and Alphitonia (Australian-Indo-Malayan, the Hawaiian species not very distinct) belong to the Rhamneae, Pleuranthodes (endemic in Hawaii) and Gouania to the tribe Gouanieae. Certainly neither of these groups has a distinct center in America at present, and to state anything about their "primary concentration" is to say too much.

18 Comments by Brown: Alectryon macrococcum seems to have been an arid land food plant of the ancient Hawaiians and may have been introduced by them. Our present knowledge of the genus and distribution of species makes it impossible to regard with certainty the species as indigenous to the Hawaiian islands. The genus ranges from Australia and New Zealand northward to the Philippines. A. macrococcum is closely related if not identical with species occurring in the region of New Zealand. The probable existence of several species of Dodonaea in American Eocene seems well sustained by the impressions of the leaves and the fruits.

Comments by SKoтTSBERG: I prefer to keep to the facts about the distribution of the living Dodonaea species.

19 Comments by Brown: Metrosideros' seems too well represented in the region of Australia to be considered "decidedly Polynesian." The distribution of existing and fossil representatives of the family, and the definite connection of the Metrosiderinae with the American center, are only a few of the facts which must be taken into account in a discussion of the origin of the Polynesian representatives. Syzygium (closely related if not synonymous with the American Eugenia) is closely connected with the American center-apparently the dominant center of the Myrtaceae.

Comments by SkoT'TsBerg: It may be better to call Metrosideros AustralianPolynesian: this does not alter my conclusions. What Brown understands by the "definite connection of the Metrosiderinae with the American center" is not clear to me. The group has one solitary representative in America, Tepualia stipularis Griseb. (Southwes't Chile), most likely belonging to the old Antarctic element so well represented in the south. Syzygium is not synonymous with Eugenia. The family has two centers, tropical America and Australia. Hawaii is connected with the Australian center, not with the American. If we derive the Metrosiderinae from America, we may as well reduce the entire Australian myrtaceous flora to a branch of the American, and this is, perhaps, what Brown really wants to do. Then he has no difficulty to make the Hawaiian flora "Ioo\% American."

20 Comments by Brown: Rhus centers definitely in Africa ( $75+$ species), the primary center of the tribe and family. A secondary but aggressive center with about half as many species occurs in America. Comparatively few species occur in Asia or the Malay regions. The Hawaiian-Asiatic species belong to a section common to America and Asia (one species of Persia extending into the Mediterranean region) and is closely allied to the American Rhus copallina $L$. Both the distribution of living 
Of course there are other plant groups for which an American origin presents itself for discussion, otherwise the entire American element in Hawaii had better be referred to the fairy tales, but the families just mentioned do not appear to be happily chosen. I certainly do not deny that they are the largest families found in the lower Eocene of the Mississippi valley, but I am pretty sure that they are about equally well represented in the Eocene of many other countries.

Of course Brown is familiar with the fact that many Hawaiian plants have their closest relatives in the region extending from Australia to Malesia, but nevertheless he supposes that the "true" affinities are with Isthmian America, whence both Hawaiian and Indo-Malayan species were derived. For many species his theory does not lend itself as an explanation of facts (p. I6), and cautious paleontologists will say that for many plants a true affinity cannot be established on the basis of fossil leaf impressions.

In a later paper Brown ${ }^{21}$ has treated the same subject. Here he calls the most ancient group the American element, identical with his first dispersal wave and entirely an American derivate. The second is said to be partly American, but mainly Malayan or Australian (p. 222) and is called the Indo-Malayan element. He continues (p. 224): "this element is largely Indo-Malayan or Australasian in its affinities, but in all probability these plants are of American origin." I think it right to ask for

species and the fossils of the American Lower Eocene favor the conclusion that the Hawaiian variety may have originated from the American center, in common probably with its close Asiatic relatives.

Comments by SKo'TSBERG: I can only repeat that the Hawaiian Rhus is a local form of the widespread but exclusively Asiatic $R h$. semialata. I do not enter upon the earlier history of the genus, but I should perhaps call attention to the old connection across the Bering Sea between Asia and America, where, however, Hawaii is not involved. Besides', Brown seems to have forgotten that the main object with my discussion of these families of the "second dispersal wave" was to show that they are not abundantly represented in Hawaii. And I think I have shown this.

21 Comments by Brown: Here and following there is confusion regarding the dates of the two papers' cited. "Secondary Xylem" was written in 1918 and was published in 1922 without complete revision. Because of my absence from Honolulu, there was no opportunity to read proof. My views are more accurately expressed in "Origin of Hawaiian Flora," written in 1920, where the following statement occurs (5, p. I35): "In many cases the closest existing relatives occur in the region of the East Indies' or Australia, but such affinities appear to be of a collateral character and remote from the center of origin. The second wave, like the first, seems to have come, in large part at least, by way of the Central American region, and during about Lower Eocene time." The distribution of both existing and fossil plants indicate that, in many cases, the Hawaiian representatives have not come from the direction indicated in the closest affinities.

Comments by SkotTSBERG: There is no confusion of dates on my part, I have called them earlier or later according to the date of publication, which is, I believe, general practice. "Secondary Xylem" is stated, on the back of the title, to have been used as a thesis "in a somewhat different form" in 1918, but was published in its present shape in 1922, which date should be quoted. (See p. 27.) 
convincing proofs supporting this most remarkable statement which goes against all results of the genetic plant geography. If this statement be accepted it is useless and hopeless to draw any conclusions on the history of the plant world from the features offered by its actual distribution.

Brown has supplied a chart showing the equatorial Atlantic currents passing into the Pacific and reaching Hawaii. It is well to be careful not to construct geophysical conditions to suit a special theory without considering the general consequences. Suppose that a break across the Isthmus of Central America is sufficient to deflect the Atlantic current, what will be the result? There will be no Gulf Stream, and the hydrographical conditions in the Atlantic will become greatly changed. And has due regard been taken of the equatorial counter current in the Pacific? Besides, competent judges have told me that a break through the Isthmian region will not affect, at least to any large extent, the current conditions in the Atlantic. The present northern equatorial current in the Pacific runs west; arriving at the island barrier Philippines-New Guinea it does not pass through the numerous passages between the islands into the Indian Ocean. ${ }^{22}$ Nothing is known of the currents of the lower Eocene, not to speak of the Jurassic. If the position of the poles was a different one during early Tertiary times, as many believe, the equator and the equatorial currents did not pass along the latitudes where they are now found. Finally, if there is any truth in Wegener's hypothesis (p. 42), there were no Atlantic equatorial currents at all when Brown's dispersal waves were in action.

Brown (4) supposes that the ancestors of the Lobelioids inhabited an elevated region in Isthmian lands. When the waters started to flow over the Isthmus, the sea level crept up and reached "the zone of the Lobelioideae" (p. 229). Their fruits were dropped into the ocean and carried to Hawaii, later followed by the Compositae, which lived at a still greater altitude. But if a subsidence took place, can it be expected that it did not influence the vertical position of these regions? If, as is generally accepted, the movement was slow, a gradual change of regional climates followed and a corresponding adjustment of regions to the new conditions; when the sea level reached the former Lobelia-zone, its plants had of course withdrawn. ${ }^{23}$ The montane vegetation did not remain to be

22 Comments by Brown: A moderate submergence of the East Indian region would connect the Indian Ocean with the Pacific over the upper Malay Peninsula.

Comments' by SkotTSBERG: This may be true, but we cannot say when the submergence will become sufficient to upset the Pacific current system.

23 Comments by Brown: There is no statement of this kind in either paper. With progressive surf erosion, drift may be derived in large part from comparatively high levels, the undermining at surf-line causing repeated landslides'.

Comments by SkotTsBERG: Of course I have never accused Brown of anything 
carried to Hawaii; the only chance would be that under these conditions new species were formed in the basal region (p. 23). If the Atlantic waters broke into the Pacific as the result of a catastrophal submergence, a wholesale destruction of the montane vegetation suddenly brought under the conditions of a tropical shore might have followed.

In his first paper Brown looked for support of his two-wave theory in the anatomy of the wood. The older immigrants had smaller vessels, average diameter $0.12 \mathrm{~mm}$., the younger ones averaged 0.14. The difference seems small, but if such types as I for other reasons judge to be more ancient in Hawaii had a diameter of say o.Io-0.14; the younger, o.I2-0.I6; and the earth's vegetation had been largely examined and had shown something of the same difference between old and young groups, some truth might be hidden here. But first of all, the relative size of the vessels within each family should be examined: a diameter, large in one example, is quite small in another. "Plants which have been longest in the islands have (without exception so far as I am aware) vessels of extraordinary small caliber" (5, p. I 37$)$. Of the 322 species referred to (in fact, they are more numerous, as a considerable number of lately described species have been omitted) the most ancient group, only fifteen have been examined, among them not one of the Lobelioideae and only one of the Compositae. ${ }^{24}$ In the Secondary Xylem less attention was paid to the bearing of this character on the age of the flora: all the seventyone species examined are regarded as "the endemic series," with an average vessel diameter of 0.13 . If we stick to the division into two groups, the range of variation in the older is $0.05-0.20^{25}$ (apparently congeneric

like this statement. I have only drawn some nearby conclusions from what he says. His theory is' now completed by a new idea, that does not make it more acceptable, for I have great difficulty to imagine a surf erosion sufficient to cause landslides of the required proportions and make the montane flora drop into the sea.

24 Comments by BROWN: When the 1920 paper was written, the cross-section of nearly all woody species had been examined.

Comments by SkorrsBERG: I could keep to the published facts only and did not know that the anatomical examination had been extended.

25 Comments by Brown: The source for these figures is not stated. I have published no data on range of variation, but my studies show that these figures are incorrectly compiled. The range of variation in vessel diameter in the older group is $.02-.18 \mathrm{~mm}$. and in the younger $.06-.25 \mathrm{~mm}$. Although these figures are quite tentative and may undergo revision, it is believed that they fairly represent the variation of vessel diameter of one group relative to the other.

Comments by Sko'TTSBERG: My figures were derived from Brown's papers. The species were grouped according to the indications in 5 , p. I35, and the range of variation determined from the anatomical paper (4). My maximum figure 0.2 for the older group is better replaced by 0.18 ; it referred to the statement that in "Gossypium drynarioides" the vessel diameter sometimes exceeds 0.18 and was approximate-I willingly take it back. The minimum figure 0.02 is not found in Brown's paper. My minimum figure 0.03 for the younger group is taken from Rhus with late wood vessels of that caliber, but probably that figure should be excluded. The figure next in size is, however, 0.05 (Pittosporum glomeratum) and not 0.06 . 
species may differ considerably), and in the younger 0.03-0.25. The vessel diameter is largely a physiological character. Until a better knowledge is gained not only of Hawaiian, but also of other plants in other parts of the world, where there is reason to suspect that old and young elements are mixed, the question of age in relation to vessel-diameter remains open. Brown's theory is that the moist uniform Hawaiian climate has brought about a reduction of vessel diameter, which is said to be greater in continental species, and various introduced plants with large vessels are mentioned as proofs.

\section{INSULAR FLORAS AND TRANSOCEANIC MIGRATION}

This brief outlook on the floras of Juan Fernandez and Hawaii has shown that between them no direct or striking systematic relations can be established, but that many features indicate a similar history. If it be remembered that both groups of islands are entirely volcanic, that geology and topography suggest roughly the same age for both, that the climates are similar and that certain not unimportant features in the plant and animal life are common to both, it is reasonable to regard them as of the same class. If one is purely oceanic, the other also is; if one is continental, the same holds good for the other.

The two different opinions of the history of isolated island floras are irreconcilable. When an advocate for the oceanic origin meets with insuperable obstacles and tries to improve the situation by admitting former "stepping-stones," these do not help at all or only in a few special cases. The gap between the two theories, oceanic and continental, is not bridged over. Geographers and geologists generally are reluctant to assume great changes in the distribution of land and sea; biologists, unless they have occupied themselves with winged beasts, in whose power of flight they have full confidence, have often demanded land connections.

Nobody denies that there are active and valuable dispersal agencies. As an example of what they can perform: I find it possible that the occurrence of a small number of Magellanic plants on the summit of Mas-afuera island is due to stray visits of birds from south Chile, the distance being 500 to 1000 miles and the winds favorable. I have also suggested that the occurrence of a few plants of Elaphoglossum lindenii Moore, a tropical American fern, on an exposed cliff on Mas-a-tierra island might be explained as a rare instance of spore-dispersal during one of the infrequent northerly gales. The greater the distance, the less probable an aërial migration, even of light spores.

The regular ocean currents are more effective, and Guppy (I4) has made valuable studies along this line. He has revealed a wealth of inter- 
esting facts concerning the transport of fruits and seeds in the Pacific and elsewhere. But even if his results be ever so reliable, his far-reaching conclusions are hypothetical. Guppy believes that inland floras of isolated islands have, in part, originated from widely wandering seaside plants. All that is known is that there are many shore specimens-few compared with the total number of phanerogams-with buoyant fruits or seeds retaining their power of germination for a long time and after prolonged immersion in sea water, and that, for this very reason, these species are widely distributed, some even pan-tropical. Beyond this nothing is known and as soon as we let these species play the rôle of ancestors of inland endemic species or genera, firm ground is abandoned. It goes without saying that faithful Darwinists have contributed largely to the success of such a theory.

The efficiency of transoceanic current dispersal is worthy of consideration. Observation has revealed the occurrence, in many distant and more or less isolated places, of a number of identical shore plants. Their fruits or seeds have been found in drift, and experiments prove their buoyancy and give exact figures. But there is one important experiment that cannot be carried out. Millions of seeds and fruits may be thrown into the ocean, but their fate cannot be followed. If their history could be traced the record would be something like the following: ( I) only few plants are able to be carried long distances, as across wide expanses of water; (2) most of these are seaside species; (3) pronounced inland species would, cven if their dispersal units were brought down to the shore and carried off, hardly ever arrive at a suitable station; (4) even of the shore species, only a very small proportion of the seeds or fruits is transported a long distance and safely landed; (5) few of these seeds land on a spot where they can germinate; (6) even in a suitable place, only a part of the seeds germinate; (7) a portion of the young plants is likely to perish; (8) of many species, the new arrivals do not flower and seed and thus are unable to establish themselves; (9) many species, apparently established, disappear again.

It may safely be said that, as a rule, even species eminently fitted for ocean dispersal extend their areas at a very slow rate. Most species have little or no chance to use this agency, a consideration which eventually compels the dismissal of the thought that the entire Hawaiian flora may have immigrated by means of ocean currents.

It must be rarer still that distances amounting to several thousand miles are covered by wind-carried seeds. As a rule even light spores do not travel across oceans. Ferns or bryophytes are not mixed pell-mell over the globe but form distinct floras with many endemics; relation- 
ships similar to those of the phanerogams can often be traced. It is true that many fungi and lichens have a surprisingly wide area, but it does not follow that they easily travel from Europe to America or from Africa to Australia.

That birds carry fruits or seeds in their stomach or plumage, or in mud on their feet is of course true, and nobody doubts that birds are active disseminators of plants but hardly when it comes to very long distances. And there is no lack of seeds that do not float, cannot be carried by winds and are despised by birds.

With these facts in mind, how is the endemic flora of islands like Juan Fernandez or Hawaii to be explained? In Juan Fernandez 69 per cent of the phanerogams, practically the whole forest flora, is endemic; in Hawaii the figure is about 80 per cent, and 90 per cent of the forest trees are included. How can the fact that Tetragonia expansa is all round the southern Pacific or that Ipomaea pescaprae inhabits sandy seashores in all tropical regions explain the origin of isolated endemic floras? Of course only if the theory of efficient trans-oceanic migration is completed by some other hypothesis. It has been supposed either that these endemics formerly existed elsewhere and have become extinct except in the little island where they are now found, or that they have originated in the island from unknown ancestors, undergoing a change that, for many of them, has become so profound that their relationships are veiled in impenetrable mystery. At first sight one would perhaps give preference to the first alternative, dispersal and dying-out working together, but no plantgeographers believe in this as a general cause. The second theory has been universally adopted. It has its difficulties, for it requires a greater antiquity for some volcanic islands than is admitted by geologists.

It is beyond doubt that the relict theory satisfactorily explains some facts of distribution. Paleontology bears witness to this, even if the most famous examples like Sequoia or Taxodium do not concern island floras. In general it is safe to say only that a certain type once covered a greater area, without explaining how it was able to cross the ocean.

The theory on insular creation of genera and species rests on the supposition that, when a plant arrived on one of these islands, where there was still ample space, it became modified through the new and strange conditions, it exploded into many forms, and selection set in. Rock's conclusion regarding the origin of the Lobelioideae (23) is typical of this manner of looking at things. He accepts a small number of ancestors, some from America, one from Himalaya, one from Africa and one from Australia, which were so struck by the favorable conditions on isolated Hawaii that they developed seven genera and nearly I50 species-really 
many more, as innumerable connecting links are supposed to have died out. It is surprising that ancestors from all directions would have, as it were, made an appointment to meet in the center of the Pacific. But both theories, dying-out and new creation, join in a firm belief in a reckless trans-oceanic migration. As there is little chance for a forest tree from the cool mountains to find a new home on a tropical seashore and, from there, wander inland, most authors put their faith in the capability of birds. Unfortunately, the real long-distance flyers are marine birds with a marine diet and do not come into contact with the inland vegetation, except under unusual conditions. In Juan Fernandez, distant only 360 miles from the nearest coast, many of the birds are endemic and never go far from the islands, others are of little use for conveying heavy seeds or fruits. Stray visitors are probably responsible for the introduction of a few semiaquatic plants or weeds. The same statement applies to Hawaii, only the fauna is much more peculiar and more strictly confined within the small insular area. Most of the forest plants do not possess dispersal units fitted for wind-transport, but drupes are not uncommon.

The coral islands, generally regarded as recent, are inhabited by species potent of long journeys and scarcely any endemism is found. I am not so sure that all these islands have become populated so very recently; counted by thousands of years, perhaps, they have not given birth to peculiar species. Their high degree of isolation has never been questioned. Even if they do not offer conditions comparable to those of a mountainous island, they ought to have produced something. At Krakatoa, also referred to by Campbell (7), a new plant cover has been formed since its destruction in 1883 . This island lies, however, less than fifty miles from such enormously rich floral regions as Sumatra and Java. Such illustrations are of little value for the understanding of Hawaii or similar islands. Krakatoa is not oceanic, and is not expected to develop endemic plants. Coral islands have little space for upland vegetation. The logical conclusion usually is that endemism requires suitable inland stations and a high degree of long isolation.

\section{ISOLATED ISLANDS AND ORIGIN OF SPECIES}

Thus arises the great problem: the origin of species or, as I prefer to express it, the reasons for change and development. This question is inseparable from the island problem. The plant world during bygone ages was different from the present plant world; the farther back, the more unlike. It is said that the new plant life has developed from the old, but the changes have only been partial, as types of immense age have still persisted without having any great change and without showing 
signs of degeneration. Existing knowledge gives no right to regard islands from any special viewpoint.

Advocates of the oceanic nature of Hawaii say that the plants that grew from stranded and landed seeds lost, as it were, their balance. Their offspring varied in all directions and natural selection preserved and modelled what was fit for the new conditions, the changes went on and on until the ancestors of many plants can no longer be recognized. As immigration was quite accidental, the same ancestor did not arrive, on an average, more than once so that evolution could proceed with a minimum of disturbance. As to the cause of evolution, authors seem to agree: the new virgin soil and the new conditions. However, experience teaches that, provided the conditions are about the same as in the country where the seeds come from, the plants may establish themselves and remain unchanged, and if not, they will not live in the new place. The weak point is of course that experience does not go back more than a few hundred years, but I fail to see that one thousand or ten thousand years would make any difference so long as no new, unknown factor is brought into action. Experience also teaches that there are many species more or less anthropochorous able to live under very different conditions and still remain the same. Evidently there is some essential combination of external factors that enables them to do so, otherwise there should not be so many weeds common to Sweden, Chile and New Zealand, regions where soil and climatic and indigenous floras are very different. It is also known that many foreign plants may be grown in gardens without providing especially for them, and furthermore that many species are very sensitive, very stenotopic.

Certainly I do not want to say that a change of external conditions never has any influence. Modifications are known, which become fixed by external factors such as temperature and remain constant under the new conditions. There is also another possibility. A species (perhaps most species) is an aggregation of genotypes, it is "variable or polymorphic." Nature has produced a multitude of genetic combinations: within the total area of distribution of a species, certain combinations are more vital in one district, other combinations are more vital in another district. There are homozygotic and heterozygotic genotypes, and the phaenotypes may be quite recognizable and so unlike each other as to be described as varities, subspecies and microspecies. The breaking up of an area may kill many combinations and make the remaining ones more distinct; selection may work in the same direction and favor the survival of new combinations, where there are possibilities for their origin, for selection itself or adaptation does not create new characters. While 
studying the flora of Juan Fernandez I was confronted with the question of vicarious species. I thought that the starting point might be a polymorphic species, broken up by isolation. Much better examples are offered by the Galapagos Islands and probably also by Hawaii. It was highly gratifying to learn that modern genetic studies point in the same direction. Turesson (29) has found that a change in external conditions - such as may result from the removal of species to a new place-may create life-conditions for new combinations of Mendelian factors and thus realize new genotypes and eventually phaenotypes. This theory is in accord with experience of local races and may throw some light on vicarious species in Hawaii and elsewhere. But it does not imply that there is always a fixed relation between a genotype and its surroundings; the genotype is not a product of environment in the old adaptation sense. It is of course "adapted" to the place or it could not live there, but it may be able to grow in other places as well, to which it had no chance to go. Also several genotypes may occur on the same spot. Mere topographical isolation is often the reason why a certain form is endemic.

For example, the seeds of one homozygotic and phaenotypically distinct individual within a polymorphous species are introduced only once in a distant country where the species had not previously existed. The local race thus established will perhaps receive a Latin name and be considered as an endemic form, while its existence in its original home is obscured by the multitude of genetic combinations existing there. Nature is of course a great experimentator. Perhaps the Hawaiian Vitex trifolia L. var. unifoliata may be regarded as an incipient endemic. According to Hillebrand (I7) there are no entirely trifoliate plants in Hawaii; the partly monophyllous form has, however, been found in Australia and in Asia. If it happened to be rare in these countries and finally disappeared, the Hawaiian form would become endemic.

Even if it were possible to understand how a number of local forms have arisen, the recombination of Mendelian factors does not account for the great changes, the "evolution" that plays the sovereign part in the speculation of Engler (I Ia), Drude (II), Johow (I9) and others who have written on insular floras. Experience promises no explanation. The question may be stated thus: if climatic and edaphic changes occur in a country already covered by vegetation, do the plants respond by forming new species and genera to harmonize with the altered conditions? Suppose that the temperature of Hawaii is lowered a little; it can only be predicted that some species will die while others will extend their range. In many cases exactly this has happened in other parts of the world.

To take one example, during the post-glacial, so-called subatlantic 
period in Scandinavia, as illustrated in our peatbogs and other depositr, the deterioration of the climate resulted in a general march southward of the northern limit of many plants, among which the hazel (Corylus avellana L.) and water chestnut (Trapa natans L.) have been studied in detail. Although the change must have been gradual, tender species did not develop hardier forms but simply died out within a more or less wide zone. Trapa almost disappeared from Scandinavia. I have studied both Juan Fernandez and Hawaii in the field and $I$ have the strongest impression that the native vegetation in both places is to a considerable extent decidedly stenoclimatic. There are numerous species that appear to be on the verge of extinction, quite regardless of the influence of man, clumps of a few individuals in a few places or even in a single spot. They show no tendency whatsoever to extend their area. I could not free myself from the impression that, if the conditions were altered ever so little, the chances are a hundred to one that destruction would follow. The changes due to man tend to favor the rapid spread of introduced species.

There appears to be no explanation for what is called "evolution." Lamarckism or Darwinism or other "isms" do not reach the kernel of the problem and partly disagree with the results of modern genetic studies. It is necessary to believe that evolution results from the introduction of some new and unknown moment, causing the changes of genes or creation of new ones. Recent studies of the number of cromosomes in large genera seem to show that an increase of the number may be one of the modes of species-making (16). The relations between such internal processes and the external conditions are not known. It is known that if a continental species arrives upon an island it will take possession of ground or disappear; but it is not known that it will form new species. Why should the insular environment more than any other induce genetic activity?

The question of species creation applies in like manner to the continents. Take a country like South America before the formation of the great, still geologically young Andean chain. These mountains are stocked with a flora rich in endemic species, many of limited distribution, with many endemic genera belonging to very different families and admirably adapted to alpine conditions of life. Where did the flora come from? Is there not a casual connection between the formation of the mountains and the origin of their flora? I suppose most people believe that alpine floras are, upon the whole, younger than the lowland vegetation. The mode of development of all these alpine species, many but not all related apparently to lowland species, is quite unknown. I shall add one remark here: 
there seems to be a difference between Hawaii and Juan Fernandez in this respect. In Juan Fernandez only Mas-a-fuera, the higher of the two islands, has a special mountain flora, but very few alpine species are related to lowland forms (perhaps species of Erigeron) from these islands, although such examples may be more common in Hawaii.

A high percentage of endemics is not characteristic of oceanic islands. It is sufficient to mention West Australia or Cape Colony. Islands do not stand in a class by themselves; the evolutionary forces have acted likewise on continents. There is no obvious reason why seeds should give rise to new genera or species only because they happen to be carried to an isolated island. From the fact that an island flora is rich in endemics it is not reasonable to conclude that it is either oceanic or continental.

It is a current idea that the statistical composition of an insular flora is a proof of its oceanic character. (See for example, Solms, 27). Such floras have been called fragmentary. But the same character may result from isolation through transgression and disappearance of land, provided the distance is large enough to prevent most plants from immigrating and the isolation took place a long time ago. Changes like glaciation affecting extensive regions had a greater influence on continents than on islands surrounded by wide expanses of water. In the wandering of plants over continental areas there is a tendency to level the distinctions between their different parts, with little or no influence on isolated islands where more stability reigns. Consequently time tends to widen the floristic differences between an island and its mother continent, and these differences show in the statistics. Nevertheless, Willis (33) has taken pains to show that it is not a question of a fundamental difference, but that the same laws rule everywhere.

\section{OVERESTIMATION OF TRANSOCEANIC MIGRATION}

Both Juan Fernandez and Hawaii are volcanic islands of no great geologic age; the Juan Fernandez rocks are late Tertiary according to petrographers. The floras of the two island groups are rich in isolated types: their character is not in close accordance with the youthful appearance of the soil. There are types dating back to early Tertiary or even pre-Tertiary times such as Thyrsopteris in Juan Fernandez, with no near relatives at all; like a Sequioa among ferns. It is probable that genera like Lactoris, Dendroseris, Brighamia or Hesperomannia have not originated from invading "germs" during the Pleistocene or even Pliocene, unless it can be shown that their ancestors recently lived somewhere else and became exterminated. For a single genus such an explanation might be acceptable, but it is not the question of few plant forms but of very many, and not 
only on Juan Fernandez and Hawaii but on all islands of the same character. If there was not a general destruction of allied genera and species at such a late date as required, there must be attributed a higher age to these island floras than indicated by geology. These present floras were not created on these islands, but existed long before on other soil and took possession of the cooling volcanic masses, while their former home disappeared through submergence and under the lava streams. Part of this process is still going on in the island of Hawaii, new soil is formed by volcanic eruptions, and in the humid districts the lava flows become gradually covered by fresh vegetation.

Some geographers and geologists believe that the volcano Etna emerged off shore near the coast of Sicily, then became attached to the island by filling the intervening straits and covered part of the island by lava streams. It does not require much imagination to see Etna gradually cover the whole island with basaltic beds. The vegetation, at least a part of it, will survive and take possession of the new soil. If then the volcanic activity ceases, the craters break down, and erosion cuts out valleys and ridges, the result will be an island like Juan Fernandez, where the original eruption centers have disappeared. If such has been the last stage in the formation of these islands, the flora may very well show signs of considerable age. But if former land connections did not exist, an understanding of its origin and composition is not possible, unless unlimited faith is placed in transoceanic dispersal. This I cannot do.

There is a Polynesian (roughly defined) element in Juan Fernandez. But why is there not, save for a couple of widespread littorals, a single identical species on both sides of the ocean? In spite of favorable winds and currents, this element evidently is not recruited by new additions, nor has it been for ages. Logs of Chilean trees are sometimes carried to the shores of the islands; I have observed them in Mas-a-fuera, always much waterworn and without a trace of bark they seem useless as carriers of plants and seeds. And few people will believe that the Hawaiian flora nowadays receives new species other than through human agency. That now and then spores of cryptograms reach remote islands has never been disputed, but such happy instances do not lend themselves to far-reaching conclusions. The embarrassing fact remains that oversea migration has practically ceased altogether. This is recognized by Guppy, who turns to the supplementary theory that the natural agencies, that were so wonderfully effective during bygone ages, have lost their efficiency. He gives no reply to the questions "how" or "why," it suffices that they have played out their rôle. The currents perhaps changed their course, the winds blew from other directions, the birds have died out, gone elsewhere, or acquired new 
habits. For my part I find it easier to believe that their performances have been largely overestimated, and this opinion is strengthened by the following observations.

There is a considerable floristic difference between Mas-a-tierra and Mas-a-fuera, distant little more than 9o miles from each other. Only I9 per cent of 142 phanerogams are found in both islands. The exchange between them must be very limited-and the "ancestors" must have crossed the ocean in the most adventurous manner! The transporting agencies are pretty near helpless even for this short distance. There are, for instance, seven species of Dendroseris (Compositae) in Mas-a-tierra, and three quite different ones in Mas-a-fuera where, besides, most of the endemic genera, among them such as have drupes and achenes with pappus or minute seeds, are absent. The same conditions are found in Hawaii. Rock (23) discusses the distribution of the Lobelioideae and declares that interisland traffic has ceased. I want to add that according to my belief the Hawaiian islands are continental, not permanently oceanic, that they have all been continuous and that, after they became separated by broad straits, the exchange of plants has been very slight. It is of course also possible that the difference between them has been deepened by later evolution (probably contemporaneous) of different species in the different islands.

I know that many geologists and zoologists are opposed to such speculations, but also that many biologists are firm believers in the continental nature of Hawaii. If I decline to discuss zoological questions here it is not because I think it proper to look at this problem only from a botanist's standpoint. I am quite willing to postpone my final judgment until we know more and have gathered more material from all the branches of science involved-and they are many.

Although the acceptance of a continental character will, from a botanical standpoint, give a satisfactory explanation of existing conditions, a few obvious anomalies are met with, perhaps standing in better light if viewed from the oceanic theory. It is important to note that these anomalies do not concern the presence, but the absence of certain groups of animals and plants. For example, on many islands the absence of conifers and orchids. The cones of conifers will sink in water and the seeds are large and heavy. The orchid seeds are small and light but delicate and apt to lose their germinative power. Johow (19) pays great attention to this question when dealing with Juan Fernandez. See also Wallace (31). There are a small number of conifers in Southern Chile of which some at least should be able tc exist upon the islands, had they arrived there; but Juan Fernandez may have become isolated before these conifers reached their present home. The 
same may be true of the southern beeches (Nothofagus), dominating south of latitude 40', where they are mixed with such genera as Drimys or Myrceugenia, which also form the bulk of the forest in Juan Fernandez, where Nothofagus is wanting. Orchids are rare in the lowlands of rainy Southern Chile and very scarce in Western Patagonia and Fuegia. Other large Chilean families almost wanting are Scrophulariaceae and Leguminosae. Of Scrophulariaceae there is only a Mimulus, very near a Chilean species, and the highly peculiar Euphrasia formosissima Skottsb. It is difficult to see how isolation would check the development of this family more than other families. The seeds are often very small, of a kind supposed to adhere to mud on birds' feet, and they retain their power of germination long enough. But the Scrophulariaceae of Chile belong to the true Andine flora and possibly never had a chance to spread to the islands. Of Leguminosae it is significant that the two species of Sophora sect. Edwardsia, which alone represent this family in Juan Fernandez, are closely related to one Chilean and two New Zealand species. The family is poorly represented in the rainy region of Chile west of the Cordillera, so that we cannot expect many species in the islands whether they have been always isolated or not. There are several families well developed in Chile but wanting in the islands, while others possessing no better facilities of dispersal occur in both places.

In Hawaii, three orchids are found and several Leguminosae, but of Scrophulariaceae only the widespread Herpestis monniera H. B. K. There are no conifers, though numerous cultivated species do very well. Still it cannot be said that the absence of a species proves that an island has always been isolated. It is quite possible that even during a more continental stage many plants never succeeded in reaching the future island. Even overland dispersal is, generally, slow. But it is of course necessary to direct attention to notable cases of absence of species, especially if they concern many islands in different parts of the world.

\section{A SKETCH OF THE HISTORY OF JUAN FERNANDEZ FLORA}

The present trend of the South American Pacific coast is determined by the Andes, but before the uprising of these enormous mountains the coast line was doubtless different in form and position. A considerable submergence has probably taken place, resulting in a more or less complete disfiguration of the ancient coast and accompanied by an outflow of volcanic material. The abysmal depressions in the ocean floor along the coast of Peru and Chile, opposite the broadest and heaviest portion of the mountain range, give a hint of what has happened. Crustal movements may have begun during Cretaceous time and continued during the Tertiary. They 
have not yet ceased altogether. A submergence of land, indicated by a submarine ridge, took place along the longitude of Juan Fernandez. These islands rest on this ridge, which continues north and carries the small islands of San Felix and San Ambrosio, remarkable for their peculiar flora. The greatest depth on the bank is given as 2,000 meters, while between it and the coast depths of 5,000 to 7,000 meters, or even more, are found. The bank runs down toward the coast south of Concepcion, with a depth not over I,250 meters, but bounded by depths of over 3,000 meters on either side. This very deep coast depression comes to an end between Valparaiso and Concepcion.

It would be meaningless to regard all submarine ridges as signs of submergence, but for the ridge on which Juan Fernandez rests, the temptation is great. The assumption of former land connection here is not in opposition to the theory of persistency of oceans. There is certainly room for movements along the borders of the Pacific, bounded as it is by obvious lines of disturbance, accompanied by volcanic activity. Such movements can be admitted without violating any fundamental laws of physical geography. Of course it is difficult to tell when Great Juan Fernandez was cut off, became submerged and was replaced by the present islands. The volcanic islands inherited a part of the original flora, among other things the old-Pacific plants of doubtful origin. The affinities of a few plants are with Northern Chile, but their ancestors may have had a much wider distribution and reached farther south during a warmer Tertiary period. The old-Pacific types came from the south; scattered remnants are found on other south Pacific islands, in Polynesia and Hawaii. They reached Juan Fernandez over southern South America, where they have disappeared, replaced by a hardier flora. The reason these types have survived in Juan Fernandez is probably a complex one: the isolation hindering competition is partly responsible, but it should also be noted that there is no climate on the coast of Chile with the same favorable combination of temperature and moisture as on Juan Fernandez.

I look for the source of the old flora in the Antarctic continent. Even if there were no fossil evidence it is necessary to assume that, in preglacial time, this great land mass was covered by a rich, partly subtropical, partly temperate vegetation, with coast and inland floras, lowland and highland species. Why should the Arctic but not the Antarctic regions have been populated by plants and animals? Geographically, the Arctic is not very independent while the Antarctic is an enormous stretch of land, an, old continent; the more probale that it was stocked with an independent fauna and flora, even if at times it was connected with other lands. Fortunately, the modern south polar expeditions have furnished sufficient proofs of 
former life. Fossil wood is known from Victoria Land and both Jurassic and Tertiary plant fossils were discovered in Graham Land by the Swedish expedition, of which I was a member. Determinations of such fossils, all leaf impressions, are often arbitrary, but it is safe to say that the Tertiary fossils found connect Subantarctic America with New Zealand across the Antarctic. The relations between these floras have been discussed ever since J. D. Hooker made his famous voyage with Captain Ross, more than eighty years ago. Long registered as a proof of a circumpolar oceanic migration, Hooker's observations now begin to stand out in a clearer light. That, for some species, an occurrence of related forms on both sides of the pole is better explained by deriving all from a northerly source and southward migrations, is willingly admitted, but these southward wanderings have been too much accentuated by Berry (2), who does not seem to think much of the original Antarctic flora, and puts a little too much faith in the determinations of the older paleontological school. But why should not the Antarctic continent have been a Tertiary floral center and a birthplace of many types?

For many years biologists have called for land connections with the south polar regions. It is gratifying to find that geologists support them. J. M. Wordie (34) says: "That Graham Land was once connected with South America must be acknowledged." I predict that the connection with New Zealand will, some day, be equally firmly established. These connections may have lasted for a longer or shorter period during the Tertiary, perhaps as late as the Pliocene, but they were cut before the Glacial Epoch. The glacial sheet swept over the continent and spared nothing: the entire Antarctic flora, save for the elements which had extended their area into subantarctic regions and, perhaps, some single moss or lichen upon a nunatak or ice-free cliff, fell a victim to the cold. In the later history of the vegetation of the globe there is not a second instance of such a magnificent destruction. It goes without saying that the Ice Age of the North could not have the same effect, owing to the very different geographical situation. Remarkably enough, this has seldom been thought of. I can find no theory that gives a better understanding of plant distribution in the far south-the remarkable disjunctions of area, the many strange, isolated genera, the circumpolar distribution of special sections of world-wide genera, the small isolated families - than the bare fact that, during the Glacial Epoch, the entire flora of a big continent was well-nigh extirpated. Willis (33) says that monotypes increase in number as we proceed southward, but as he regards this question from a "north-hemisphereal" standpoint, he arrives at an artificial explanation. Existing knowledge of Chilean fossil botany is too fragmentary to permit a reconstruction of the pre- 
Andean flora. It may be that it had a more subtropical aspect than the present flora and also that its special Chilean character was much less pronounced. It contained, I believe, a great number of Antarctic types in addition to the American types. The formation of the Andes Mountains gradually created a barrier between east and west, and there is now little or no exchange between Peru-Chile on one side and Bolivia-Brazil-Argentina on the other. Past ages account for the elements common to both. There is a possibility that derivates from tropical American ancestors, now absent from Chile, have survived on Juan Fernandez, such as Juania australis Dr., Cuminia or Boehmeria excelsa Wedd., though for all I know Boehmeria may be nearer to Polynesian species than to American species. The very conspicuous south Chilean element in Juan Fernandez contains species that, to judge from the present distribution of the genera to which they belong, must be called Andine, but also several of another type of distribution, represented not only along the Andes (especially in the south) but also in New Zealand, while many eminently Chilean types are missing. This would indicate that the connections between the islands and the main land were severed before the south Chilean flora assumed its present composition, and also before the later advancing Nothofagus flora reached these latitudes. It is hardly probable that the Magellanic species in the summit region of Mas-a-fuera date back to a remote period. Unlike the other elements, they are mostly non-endemic and nearly all show special facilities for dispersal. They are common in the Fuegian region, some of them also inhabit the Cordilleras farther north. Most likely they attained their widest distribution during the glacial period, when they also immigrated to Mas-a-fuera, or perhaps even later.

The principal difference between Juan Fernandez and Chile lies in the old-Pacific insular genera and species. I have not found it possible to explain their occurrence by the aid of direct land bridges to the west (25), but have tried to avoid such fragile constructions. I prefer to regard the Antarctic continent as a center and to lead the waves of distribution over New Zealand-Polynesia on one side and over Subantarctic America on the other. I know that this Antarctic circuit theory does not explain everything. We need not, however, be surprised that the old-Pacific types and many of the Polynesian types have disappeared from South America. Great geographical changes have taken place in this region-the upheaval of the Andes, the formation of a series of climates and glaciation. Fossil evidence of connecting types in South American deposits should be sought but such discoveries are always accidental, as most plants disappear without leaving any trace. 
REMARKS ON THE POSSIBLE ORIGIN OF THE HAWAIIAN FLORA

The Hawaiian flora shows few examples of direct systematic affinity, but some striking analogies with Juan Fernandez (p. 6). To look for analogous development is to face more serious difficulties owing to the far greater distances between Hawaii and either America or Asia. For Hawaii the bathymetrical charts do not offer any distinct suggestions; for Juan Fernandez the situation is far better. Many scientists believe in a greater Hawaii, embracing the whole archipelago and extending northwest. Campbell (7) proposed a connection between this Great Hawaii and Indo-Malaya-Polynesia through intermediate reefs and islands. Other authors prefer to connect Hawaii with America. The views of Vahl (30), an all-around scientist who does not look for support of some special theory but merely tries to form his opinion on documents from all branches of science, cannot be neglected. Vahl finds it probable that there has been land connection between the Australian-New Zealand region and such groups as the New Hebrides, Fiji, Samoa and Tonga, but that the true Polynesian islands, except Hawaii, are oceanic. He expresses the belief (30, p. 236) that, "During part of the Cretaceous, Hawaii, Galapagos and Juan Fernandez were attached to America or at least so close to the continent that the ancestors of their fauna and flora could invade them." Unfortunately, too little attention is paid by him to the non-American plants in Hawaii which includes the greater part of the flora. It is evident that Vahl postulates considerable movements in the earth's crust along the borders of the Pacific. All the islands mentioned by Vahl do occupy a border position, except Hawaii, the relations of which are difficult to explain. Of course Vahl does not mean to say that Hawaii, the Galapagos and Juan Fernandez were connected. The Galapagos Islands have nothing in common with Juan Fernandez: their flora points toward the Isthmian region. It is true that a Lipochaeta (Compositae) lives on the Galapagos Islands, while the rest of the genus is exclusively Hawaiian, but a direct connection cannot be established on this unique example; a common source should be found for the genus. It may be that a direct bridge between Hawaii and America is required, and in this connection the effect of the rising of the American mountain ranges and the possibility of a Bering Sea route should be considered. The presence in Hawaii of genera related to those in South America may indicate, according to Campbell (7) a former distribution of their ancestors along the line: America-the Antarctic-New Zealand-Polynesia-Hawaii, and a disappearance except at the two extremes of their former range. This involves an extension of my Antarctic circuit theory and looks rather daring, but it is the only manner in which to get away from transpacific bridges, if we do not believe 
in oversea migration. (See p. 20.) I cannot see how we can do without a connection between Hawaii and Micronesia. A study of the oceanographic conditions is little encouraging, and if I say that we might look in the direction of the Marshall and Caroline islands it is not because I am sure that this is the only or even the best possibility. Old eruptives are known from the Caroline islands, so they are not entirely neovolcanic. In the same region also are a series of tectonic lines, betrayed by deep sea troughs bordering the Marianas Islands, Yap, Pelew and the Philippines and associated with recent volcanic activity. In China, proofs of an enormous subsidence of post-Eocene age have lately been collected (I), sufficient, should it occur in the Pacific, to make the whole of Polynesia, Hawaii not excepted, disappear below the surface of the ocean. Movements of this kind would explain the breaking up of Polynesia and the isolation of Hawaii. It is comparatively easy to connect Hawaii with lands to the southwest, and this direction is clearly indicated by the biological affinities. The representatives in this region of American fauna and flora, even if they are few, are a stumbling-block. If there has been a connection as supposed by Vahl, it was not contemporaneous with the Polynesian. There was no transpacific bridge.

\section{THE AGE AND AREA THEORY}

Willis has summed up his many papers on "Age and Area" in a book (33), which includes a discussion of Hawaii and Juan Fernandez. The substance of his theory is contained in the following definition: "The area occupied, at any given time, in any given country, by any group of allied species at least ten in number, depends chiefly, so long as conditions remain reasonably constant, upon the ages of the species of that group in that country, but may be enormously modified by the presence of barriers such as seas, rivers, mountains, changes of climate from one region to the next, or other ecological boundaries; and the like, also by the action of man, and by other causes." Willis has taken many precautions and his intention is to establish age as the most important factor in the distribution of organisms. An example will illustrate the significance of the theory. If there is a genus with ten species in Hawaii, two of which are endemic, and one of them confined to, for example, Maui, while eight also occur outside the islands, these eight species are older than the two endemic ones, and the Maui species is younger than the other endemic species found on several of the islands. If it be assumed that of the eight non-endemic species (the "wides," as Willis terms them) three occur also in IndoMalaya, three in Polynesia and two in both Indo-Malaya and Polynesia, these two are the oldest of all ten, having attained the widest distribution. 
The same rule applies to genera. Furthermore, the two endemic Hawaiian species have originated from the "wides" of the same genus, found in Hawaii.

A species with a world-wide range, as the common bracken (Pteridium aquilinum Kuhn), is apt to be regarded as very ancient (and also very eurytopic), for we cannot well believe that its means of dispersal are materially different or much better than those of innumerable other ferns with a much more restricted range. Another example is Bystropogon (Labiatae), which has two sections, one in South America and one in the Canary Islands. Such a genus can look back upon a long history. These are general truths and they are not new. A species with a very restricted range is difficult to explain; it may be very local and depend on some special conditions for its existence, and some people will consider it an example of natural selection and special adaptation. If it is closely related to other species in the same district there is no serious objection to regarding it as a local descendant of these species-a young species. A peculiar monotype of doubtful affinity is generally assumed to be a survivor from a time when that type was better developed and showed distinct relations to other genera, a so-called relict. According to Willis this way of looking at plants is a bad habit. His rule runs: genera and species with a very restricted area must not be explained either as special adaptations or as relicts, but as young beginners. Certainly Willis does not recognize Sequoia or Ginkgo as young beginners, for there is ample geological evidence of their antiquity; they are true relicts, but in the view of Willis such examples are so rare that they do not count.

A detailed study of the flora of Ceylon first led Willis to outline his theory. He found that among the endemic species there were many which occupied a very small area, fewer with a somewhat larger area, and very few distributed over practically the whole island, and that a graduation of this kind is a fundamental feature. The Ceylon "wides" (non-endemics, also occurring outside Ceylon) are graduated in the reverse order, most of them are widely spread in Ceylon, very few are rare. The "wides" were, in general, the first arrivals in Ceylon, and most of them at least have had time to spread there. The endemics are young beginners: the rarer they are, the younger.

Willis strongly opposes the theory of natural selection. $\mathrm{He}$ finds no proof that endemics are restricted to certain localities because they are "adapted" to them: why should so many Ceylon species be adapted, for example to mountain tops and fewer to a larger area, when there is no difference in climate or soil? I am no admirer of the semi-popular explanations which emphasize adaptation, but it is a fact that many plants are 
confined to localities with special conditions. Darwinism does not teach that species, originating through natural selection to harmonize with a certain habitat, were unable to gain ground. Furthermore, what are now "wides" arose in one place and thence spread. Even a believer in natural selection may regard age as a very important factor in distribution. Darwin's theories may be rejected and still there remains the genetic response to habitat as an apparently established fact. It is not impossible that in a given country there may be numerous endemics with special wants and needs, which are rare not because they are young, but because they can find few stations within reach where they can thrive and multiply, and a smaller number of endemics able to take possession of more ground. In this distribution age may not be a factor. It is hardly probable that most endemics, as Willis thinks, will become "wides," if only sufficient time is allowed them.

According to Willis, it is remarkable that the Ceylon (and of course all other) "wides" show a gradation like the endemics, but in the reverse order, so that many are widespread in Ceylon, fewer more restricted and few local, and Willis is sure that nothing except age can explain their behavior. But a "wide" is a species that ranges over a great area, and a wide range means a wide physiological amplitude and a small amount of specialization; thus it is likely that a "wide" will find, within each separate part of its total area, many stations with acceptable external conditions. And if a species has a less wide range this may mean that it is more exacting; within each area occupied it will be less common and in some of its districts the suitable stations will be few.

Plotted graphically, "wides" and endemics show "hollow curves," which according to Willis can be explained and understood only on the basis of age and area. The same kind of curves are obtained, however, from a graphic treatment of the constituents of a plant association, or from similar statistical treatment of other material, botanical or not. The figures and curves do not reveal any new fundamental law, they are a priori to be expected and find their explanation without the aid of age and area.

It is the intention of Willis to replace the Darwin-Wallace theory with that of De Vries, who has contributed a chapter to "Age and Area." De Vries considers endemics are more or less recent mutations, that the mutation theory and the age and area theory strongly support each other. Nobody denies that there are young endemics, but to call them mutants in the sense of De Vries is to say more than is known.

Willis says it is equally impossible to explain the distribution of plants on the basis of "the relict theory." Of the dying species in Ceylon, why should so many form the class of smallest area, fewer have a somewhat 
larger range, and a few spread over the entire island? Let it be supposed that the rare species are dying out, and that this process has been going on for a long time. There will be a tendency to increase the group of very restricted species, more and more species will drop down to that group, but it is not at all necessary that they should die out at the same rate; many will linger, many are restricted but not moribund. In the group of rare endemics-the limits between all these groups of Willis are of course arbitrary-not a few species are common within their little area and very few so rare that only a handful of specimens exist. My remarks do not mean that I recommend a "relict theory" instead of the age and area theory. But what is the relict theory? So far as I know it means only that isolated genera and species, without affinities in the country where they live or even without affinities, are regarded as relicts in the sense that their systematical isolation speaks of great age of the type (not necessarily of the genetic combinations realized in the actual species), of which they are the last survivors. Even if some authors may have been a little too rash in resorting to dying-out as the cause of restriction, I have never met with a relict theory in the sense used by Willis. Who are "the supporters of general dying-out," spoken of by Willis? He has blown life into the relict theory and magnified it, only to hit it better. Willis says $(33$, p. 84), "If all or most endemics are to be regarded as relicts, then they must evidently be, on the whole, older than the wides." This conclusion is not justified. If one species of a genus presents the features of a relict, why should it be older than another, that has become and still is a wide? They have met with different fates. Age is one factor, but not the all-dominating one. Plant-geographers do not contend that the smaller area a species occupies, the older it is, that the oldest species are restricted relicts or that endemics in general are dying out. They have tried to make a careful distinction between two main types of endemism, the relict and the progressive. There are about twelve thousand endemic species in Brazil, but it will be difficult for Willis to quote an author who says that nearly all of these are dying out. Who has argued that the cactus flora of Mexico is an old, dying-out flora?

Willis regards the Hawaiian endemics as young: if we choose the genus Schiedea, which has several species, it may well be that it offers an example of progressive endemism, but the type Schiedea, as well as the monotypical Alsinidendron, are relict types and in accordance therewith of doubtful affinity, not new Hawaiian mutations of some widespread Caryophyllaceae. I am fairly sure that most botanists who have occupied themselves with the Hawaiian flora hold the same opinion. Willis considers "relict" synonymous with "dying out" or accuses his opponents of doing so. 
But the two ideas are not equivalent. There may be species that are dying out, in the sense that the number of individuals shows a steady decrease, but I am not prepared to mention a single example where human agency has not shared in this process of destruction. There are very many endemics just able to hold their ground. Prevented, for some reason, from extending their range, they will continue thus as long as they are not interfered with. Such endemics are not properly called moribund. Both kinds of endemics, relicts and young beginners, may be found among them.

The age and area theory has a corollary termed "size and space": the larger a family or genus, the older it is, the greater space it occupies. It is not dangerous to say that a large genus generally occupies a greater space than a small one; such a statement might even be called a truism. A genus with a thousand species needs much more room in order to find habitats than does a genus of ten species. Still, there are exceptions: a monotypical genus like Pteridium may be world-wide. And if it is said the larger a genus, the older, the ground becomes more unsafe. For very many genera great age has not resulted in great size and large area. If such are called relicts there are many relicts. They are indeed not "insignificant exceptions," but quite numerous in certain floras, and a study of them is more interesting than leaving them out with a view to strengthening a theory.

Finally I should like to draw attention to the "relative relicts," plants that are relicts in a certain country or district but not in others, like the Arctic-Alpine species in South Sweden or Stipa pennata L. in the same country. According to Willis such species should nearly always be young in the country, late arrivals. But if all species introduced by human agency be excluded, such newcomers are very rare and undoubtedly rarer than local relicts. These facts are lost sight of in the age and area statistics.

\section{JUAN FERNANDEZ AND AGE AND AREA}

The following rules of Willis may be examined as applied to Juan Fernandez:

I. Of endemic species, most are local, fewer rather common, few common. The wides are arranged in the reverse order. As the area of Juan Fernandez islands is very small only three classes will be considered within each group (endemics and wides). A species is referred to the highest class only when it inhabits both Masa-tierra and Mas-a-fuera. Of 95 endemics, I2 range over both islands, 55 are fairly common on their respective islands, 28 have a very restricted range. Of the 47 wides, 15 are found on both islands, I 7 are not uncommon in one island, I 5 are very local. These figures are not in accord with the age and area predictions. Among the common wides are several shore and water plants which, in all probability, 
owe their wide distribution not to greater age of the islands but to facility of dispersal. This may mean the same thing for some plants, for an easily disseminated and transported species is likely to come first. The Alpine species in Mas-a-fuera are perhaps-and this in apparent accordance with the Willis theory-the latest additions to the insular flora, but the reason they are confined to Mas-a-fuera is most likely not that they are so young, but that suitable stations are lacking in Juan Fernandez.

2. Endemics are generally young beginners. To be able to express an opinion, it is necessary to look for a "circle of affinity;" within this, the restricted insular genera should be the youngest.

Podophorus (Gramineae). Relations uncertain, probably with another monotypical genus (American).

Juania (Palmae). Forms a separate subtribe, somewhat intermediate between Morenieae and Iriarteae.

Ochagavia (Bromeliaceae). Very near the Chilean Rhodostachys, a small genus.

Lactoris forms a separate family.

Selkirkia (Borraginaceae). Isolated, lately excluded from the Cynoglosseae and brought to the Eritrichieae.

Cuminia (Labiatae). Probably nearer to Bystropogon (American section) than to any other genus.

Robinsonia and Rhetinodendron. Related to each other, but otherwise occupying an independent position in the Senecionideae.

Centaurodendron. Little known, perhaps near Centaurea, a genus very poorly developed in Chile.

Dendroseris. Nearer relations unknown; the species are divided among four sections which, if anything were to be gained by so doing, could be raised to generic rank.

Among these genera, containing 24 of the 95 endemic species, only Ochagavia, sometimes reduced to a subgenus, might be called a relatively young beginner, and this example is of course entirely hypothetical.

3. The "wides" are the first arrivals in a country. Endemics are, on an average, related to the "wides" and descend from them. Many wides in Juan Fernandez are probably recent arrivals, and few wides in the islands are likely to be older than the endemics.

Only the following genera contain both endemics and wides:

Polypogon (Gramineae): I wide, I endemic. There is no reason to consider the endemic as a descendant of the wide.

Uncinia (Cyperaceae): 4 wides, 2 endemics. The endemics are related to each other, but no taxonomist would speak positively regarding their derivation from the wides in the islands, which probably are later arrivals. 
Carex (Cyperaceae): I wide, I endemic, belonging to two very distinct sections. The wide is surely the later arrival; moreover, it has a very restricted range in the islands.

Peperomia (Piperaceae): I wide, 3 endemics. The endemics are not descendants of the wide.

Cardamine (Cruciferae): 2 wides, I endemic. The endemic is not near the wides but is close to a Chilean species.

Acaena (Rosaceae): I wide, I endemic, belonging to quite different sections.

Plantago: I wide, I endemic, having only the generic character in common.

There is not a single genus for which a genetic relation between a wide and an endemic from the same island can be traced.

4. Genera that are represented in a country by several species are likely to be (on the average) older in that country than genera that are represented only by one. Very little support for this rule comes from the Juan Fernandez flora. I suppose it holds good in some countries.

5. Endemic species of non-endemic genera in islands generally belong to large and successful families, as well as to wide-ranging genera.

By a successful family is understood a family of wide range and with many genera and species. It goes without saying that a great number of these are endemic within a smaller or larger area, and it is reasonable to expect to find island floras made up, to a great extent, of endemic members of such genera and families. Large and small families are represented in Juan Fernandez, with and without endemics. Willis thinks that if endemic species generally belonged to small families, support would be given to the "dying-out" theory. He shows that monotypes are proportionately more numerous in larger families, but from his theory the opposite might equally well be expected. A small family is young and occupies a small space, its genera are likely to be restricted, endemic, and there ought to be many monotypes, that is, "beginning genera" among them. The older a family the more large and wide-ranging genera is it likely to contain in proportion to the monotypes, unless it be assumed that every second genus from time to time gives rise to a monotype, though I cannot see why the proportion should not be equally high in the young families. But are all the monotypes, or most of them, young beginners? Seen from a systematic and genetic point of view, many are distinctly relict, and it is natural to find most of them in the largest families, which may have a longer history behind them.

My conclusions are that the Juan Fernandez flora is not in good accordance with the age and area theory. Age, in these islands, has resulted in 
small areas, never to be increased as long as the present geographical conditions prevail.

I am not familiar enough with the Hawaiian flora to make an analysis like the one for Juan Fernandez. Willis has used Hawaii for his "predictions" and probably finds that the composition of the flora is exactly what is expected from the age and area theory. It is easy to believe that in determining the rough and very general features of Hawaiian flora age is one very important factor, but I am sure a closer view will reveal many exceptions of the same kind as in Juan Fernandez. There are many genera without near relatives and altogether endemic, and most of the non-endemic genera are represented only by endemic species. If they are young beginners, they will always remain such, for they will not increase their area. I imagine that Hawaii is another exception to the age and area rule.

To be candid, I appreciate the work of Willis in pursuit of the truth, but at the same time I believe that it is more useful to analyze a flora systematically, to divide it into geographical and genetic elements, to test each example as carefully as possible and to examine all records of its geographical and geological history, making due allowance for such factors as variation of stations and climates, than simply to make a statistical survey of distribution and to conclude from the area of each genus and species, that a wide is old and an endemic young. The exceptions from the rules are probably too many to be drowned in the average figures. I believe that Dr. R. Lloyd-Praeger (22) expresses the opinion of many plant geographers when he writes that age and area "is a simple conception which has never been questioned-that the longer a species or group has existed on this earth the further will it probably have spread." But for special cases a general truth is not sufficient; the exceptions must be considered, for these give to the various floras their particular, characteristic and highly interesting features.

\section{WEGENER'S THEORY AND PACIFIC FLORAS}

In his much discussed hypothesis of the origin of continents and oceans, Wegener (32) attempts to show that as late as in the Carbonic era the continents formed one solid block. The continents consist of lighter material, the "sial," floating in the heavier "sima" like icebergs in water. The "sima" lies uncovered on the bottom of the deep seas, save for the loose deposits of organic and inorganic matter. The Atlantic Ocean was formed during the Eocene as a crevice across the block, and America became detached and started to float westward. Through the resistance of the tough "sima," the Cordilleras crumbled up along their western border. Australia, long united with America through the Antarctic continent, was detached from India- 
Africa and later also from the Antarctic, and only in the beginning of the Quaternary the present conditions had become established. America is still traveling west. Surely many geological and paleontological problems, such as the permocarbonic glaciation, and the distribution of coal find their solution in the Wegener theory if at the same time the poles are assumed to shift their position. Also the land bridges between America and Africa, Africa and India can be dispensed with. From the botanical viewpoint Irmscher (I8), finds that Wegener's theory explains most everything, provided that the poles are allowed to swing to and fro in any desired manner.

There is much in favor of a modified Wegener theory; it has aroused an unusual interest, at least in Europe, and cannot be dismissed with a haughty gesture. Still, when applied to Pacific island questions, it meets with considerable difficulties. With the continents soldered into one block the distances across the primeval sheet of water, an enlarged Pacific ocean, become much greater than they are now, and no facilities are offered to explain the remote insular floras. If, as I assume, an old Juan Fernandez was once attached to a land now forming part of the present South America, the ways of migration lie clear on Wegener's maps, and all difficulties of bridging from Australia to America are removed. But-and this is surprising-Wegener does not recognize a land connection between Juan Fernandez and Chile. He regards Juan Fernandez as an independent fragment of the "sial" sphere, covered with "sima" basalts, and assumes that the distance between the islands and the continent was, in old times, much larger than now, as the present relative position was attained only through the westward movement of America. Wegener finds support for this strange idea in one of my papers, which he cannot have read with sufficient attention. I quote him (32, p. 59): "Nach Skottsberg zeigt sie gar keine Verwandtschaft mit der doch so nahen Küste von Chile, sondern nur mit Feuerland (Luft-und Meeresströme!), Antarktika, Neuseeland und den pazifischen Inseln. Dies passt vorzüglich zu unserer Vorstellung, dass Südamerika, nach Westen wandernd, sich ihr erst in letzter Zeit so weit genähert hat, dass der Florenunterschied auffallend wird." Certainly 1 did not say anything like this, as there are obvious relations between the insular and Chilean-Andine flora. And, with the early position of South America in the Tertiary, as Wegener states it, how did sea and air currents bring plants from Fuegia any more than from Chile? Besides, where did this Juan Fernandez land come from? Was it a fragment of the primeval "sial" sphere covering the whole globe before even the Pacific Ocean was formed? This goes back to times so remote that organic life must have been in the making, and all discussions of floristic relations as expressed at present become utterly useless. Wegener believes in the relation between 
the floras of Juan Fernandez and New Zealand, but his theory does not explain this strange fact.

Wegener states that the Hawaiian islands also represent an independent piece of land. He says, correctly, that the flora is nearest related not to the American, but to that of the Old World, in spite of the fact that the currents come from America. He explains this on the assumption that in the Miocene the North Pole lay at Bering Straits, Hawaii extended between $40^{\circ}$ and $50^{\circ}$ and was under the influence of the west wind drift from Japan and China, and that the distance between Hawaii and America was far greater than now. But the floristic relations of Hawaii are with Polynesia and Indo-Malaya, not with China or Japan. And how is the American affinity at all explained? Wegener leaves the Hawaiian islands helpless in the midst of an ocean much larger than our present Pacific, while he provides the most facile communications between America and Europe-Africa. It is safe to say that if Hawaii, in the Miocene position postulated by Wegener, was stocked with plants and animals, then there should be, in the present time, a rapid exchange of organisms between the continents on both sides of the Atlantic and Indian Oceans, and no landbridges or displacement theories are needed to explain the relations. The Pacific problems have been neglected by Wegener; only look at this map (32, p. IOO) on which several Atlantic islands, such as the "Southern Antilles," Macaronesia or even Rockall have been depicted as continental fragments, while the Pacific Ocean is a great blank, in spite of Wegener's opinion that at least some of the Pacific island groups are pieces of "sial" covered by "sima" basalts.

The Hawaiian chain is said by Wegener to have obtained its present form when Asia moved northwestward (the relations between this movement and the great journey of America are not well explained) and a tension in the "sima" occurred, stretching the island chain in the same direction. The insular garlands along the eastern border of Asia became detached at the same time and got stuck in the "sima"; by the same tension the deep sea troughs were formed, at a right angle to the direction of the movement. If so, these troughs have another origin and history than the troughs bordering the American coast. It seems more probable that all these depressions are referable to a common cause.

Wegener does not attempt to discuss phytogeographical details; he expects that specialists will test his theory. But to look to Irmscher (I8) for an answer to Pacific questions is to be disappointed. Only his treatment of South America, the Antarctic and Australia-New Zealand interest here, especially as he has devoted more space to the floral history of Chile, Patagonia, and Fuegia than to other subjects. His argument is simple: 
taking the Tertiary polar movements of Wegener for granted, Irmscher proceeds to examine the fossil floras. When their otherwise acknowledged age does not fit the hypothetical position of the pole, he simply redates them in a very unceremonious manner and comes to results which no geologist will approve. If the hypothesis of pole-wanderings is accepted, anything can be proved. But the pole-wanderings remain to be demonstrated and the age of fossil floras is better known than polar journeys. To test Wegener's theory, it must be approached with fewer and less assumptions than Irmscher has adopted. Space prevents further discussion of this subject; the reader is referred to Mattfeld (2ra, p. Ioo).

\section{SUMMARY}

Juan Fernandez and Hawaii are groups of volcanic islands, very remote from each other but with common features in their flora. It is hardly probable that vegetation has originated on the islands after they had assumed their present shape; they are young islands and the flora contains many isolated types where isolation seems the result of considerable age and of geographical changes. Nor is it likely that the high endemism has resulted from an extermination, in all other countries, of all identical species of close ancestors. There is much evidence in favor of a continental origin for the Juan Fernandez flora, that it existed long before the present islands were formed and gradually took possession of them during the submergence of their old home. Part of this flora was derived from the Antarctic continent by way of South America, thus explaining the affinities with New Zealand or Polynesia. This circuit is preferred to the direct landbridges of other authors. Even Hawaii contains old-Pacific and Antarctic types, of which the original home ought to lie in the south, but the road across Polynesia to Hawaii is more difficult to trace. A better knowledge of the bathymetrical and general oceanographic features is greatly needed, as well as a critical revision of the floras. The author is confident that future investigations will show that the history of the Hawaiian flora is, in its principles, similar to that of Juan Fernandez. The disappearance of the Tertiary Antarctic flora during the Ice Age is of fundamental importance and has been greatly underrated by plant-geographers. No catastrophe of such dimensions and of such consequences has ever befallen the Tertiary flora of the Northern Hemisphere. 


\section{BIBLIOGRAPHY}

I. Andersson, J. G., Några drag ur Kinas forngeografi, Ymer., vol. 43. Stockholm, I923.

ra. Bentham, G. ANd Hooker, J. D., Genera plantarum, vol. II, p. I217, 1876.

2. BERRY, E. W., Tree ancestors, Baltimore, 1923.

3. Briquer, J., Engler, A. and Prantl, K., Natürl. Pflanzenfamilien, N. za, p. 203, 1897 .

4. Brown, Forest B. H., The secondary xylem of Hawaiian trees: B. P. Bishop Mus. Occ. Papers, vol. VIII, no. 6, I922.

5. Brown, Forest B. H., Origin of the Hawaiian flora: B. P. Bishop Mus. Sp. Pub. no. 7 (Proc. Pan-Pacific Scientific Conference, 1920) pt. I, pp. I32-I42, I92I.

6. Bryan, Wm. A., Hawaiian fauna and flora: B. P. Bishop Mus. Sp. Pub. no. 7 (Proc. Pan-Pacific Scientific Conference, 1920) pt. I, pp. I53-I58, I921.

7. CAmpbell, D. H., The derivation of the flora of Hawaii: Leland Stanford Jr. Univ. Pub., I9I9.

8. CANDOLLE, C. DE: Prodromus systemat. natur. Pars. XVI, sec. I, p. 445, 1859.

9. Candolie, C. de: The Hawaiian Peperomias: Col. of Hawaii Bull. 2, igr3.

io. Drake del Castillo, E., Remarques sur la flore de la Polynesie et sur ses' rapports avee celle des terres voisines, Paris, 1890.

II. Drude, O., Handbuch der Pflanzengeographie, Stuttgart, I89o.

i ia. Englek, A., Versuch einer Entwickelungsgeschichte der Pflanzenwelt, Leipsig, I879-1882.

I2. Engler, A., Engler and Prantl, Natürl. Pflanzenfamilien, vol. III, no. 4, I895.

I3. GREGORY, HeRbERT E., unpublished manuscript.

14. Guppy, H. B., Observations of a naturalist in the Pacific between I896 and I899, vol. II, London, 1906.

I5. Harms, H., Araliaceae: Engler and Prantl, Natürl. Pflanzenfamilien, vol. III, no. 8,1898 .

16. Heillborn, O., Chromosome numbers and dimensions, species-formation and phylogeny in the genus Carex: Hereditas, vol. V, Lund, 1924.

17. Hillebrand, Wm., Flora of the Hawaiian islands, London, New York, and Heidelberg, 1888.

18. Irmscher, E., Pflanzenverbreitung und Entwickelung der Kontinente: Mitteil. aus dem Inst. fur allg. Botanik in Hamburg, vol. V, 1922.

19. Johow, F.,.Estudios sobre la flora de las islas' de Juan Fernandez, Santiago, I8g6.

20. KLETT, W., Umfang und Inhalt der Familie der Loganiaceen: Botan. Archiv., vol. V, 3-4, Königsberg, I924.

2I. Knuth, R., Pflanzenreich, Heft 53 (IV, I29), I9I2.

21a. MatTfELd, J.: Engler, A., Botanische Jahrbücher für Systematik Pflanzengeschichte und Pflanzenographie, vol. 58, 1923. 
22. Praeger, R. Lloyd, Dispersal and distribution: Journ. of Ecology, vol. XI, 1923.

23. Rock, J. F., A monographic study of the Hawaiian species of the tribe Lobelioideae: B. P. Bishop Mus. Mem., vol. VII, no. 2, I9I9.

24. Schimper, A. F. W., Schenck, H., Beitr. zur Kennt. de Vegetation der Canarischen Inseln. Deutsche Tiefsee-Exp. "Valdivia," II, I, 1907.

25. Skotrsberg, C., Studien über die Vegetation der Juan Fernandez-Inseln. Kungl. Svenska Vet. Akad. Handl. 5I :9. Stockholm, I9I4.

26. Skotrsberk, C., The Phanerogams of the Juan Fernandez Islands: Nat. Hist. of Juan Fernandez and Easter Island, vol. II, Uppsala, 1922.

27. Solms-Laubach, H., Die leitenden Gesichtspunkte der allgemeinen Pflanzengeographie, Leipzig, 1905.

28. Thellung, A., Die Gattung Lepidium (L.) R. Br. Mitteil: Bot. Mus. Univ. Zürich, 28, 1906 .

29. Turesson, G., (2) The species and the variety as ecological units; (b) The genotypical response of the plant species to the habitat: Hereditas, vol. III, lund, Ig22.

3o. Vahl, M. og Hatт, G., Jorden og Menneskelivet, vol. II, Copenhagen, 1923.

30a. Vossische Zeitung, Feb. I6, igzo.

31. Wallace, A. R., Island life, 3d ed., London, i9ir.

32. WeGENER, A., Die Entstehung der Kontinente und Ozeane, 3d ed., Brunswick, I922.

33. Willis, J., R., Age and area, Cambridge, 1922.

34. WordiE, J. M., Geological observations in the Weddell Sea area: Roy. Soc. of Edinburgh, Trans., vol. 53, I921. 
$14+400$ 

THE UNIVERSITY OF MICHIGAN GRADUATE LIBRARY

DATE DUE

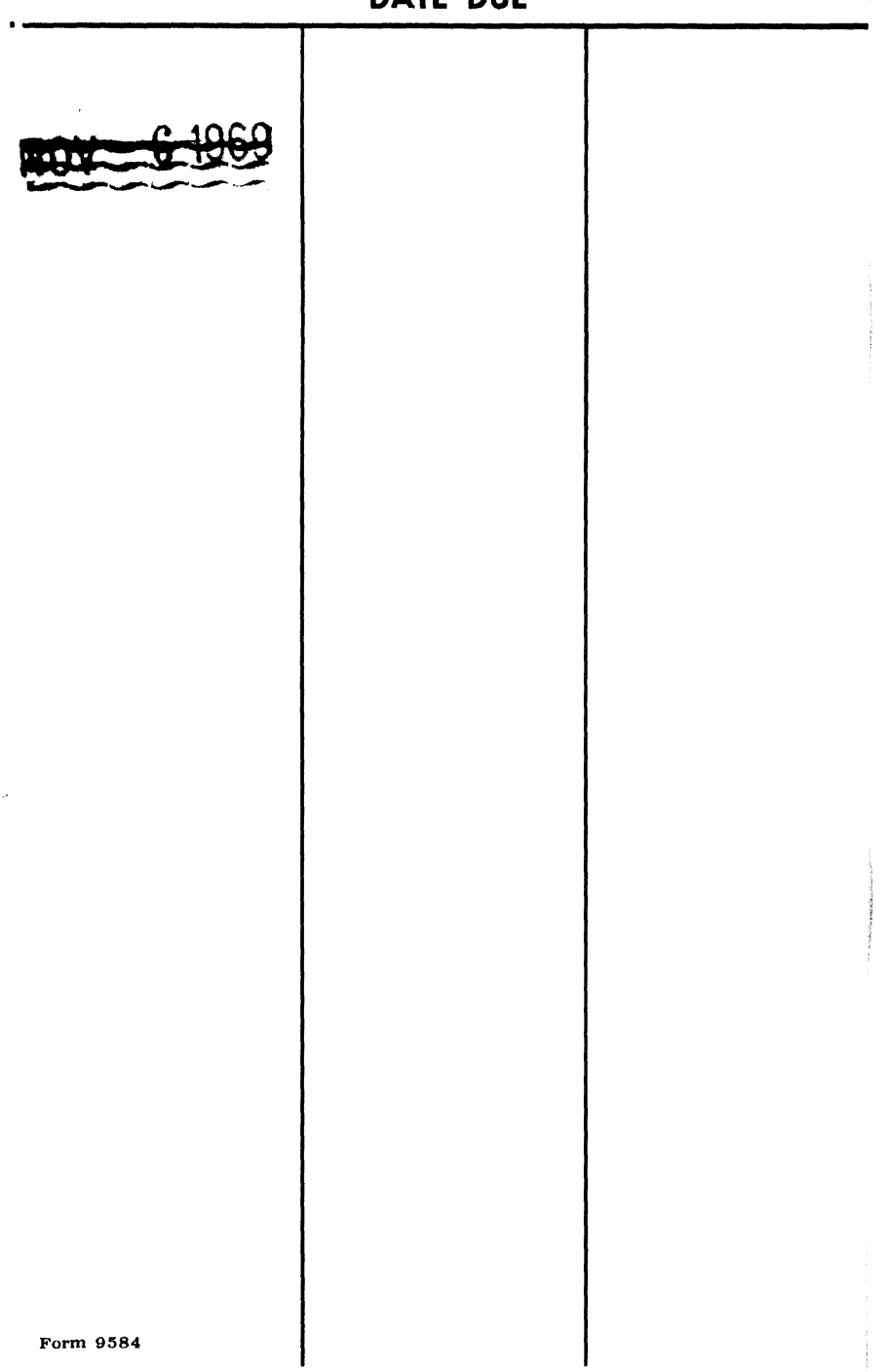


BOUND

AUG: 31944

umpry of mey. Hitratry

Filmed by Preservation

1997

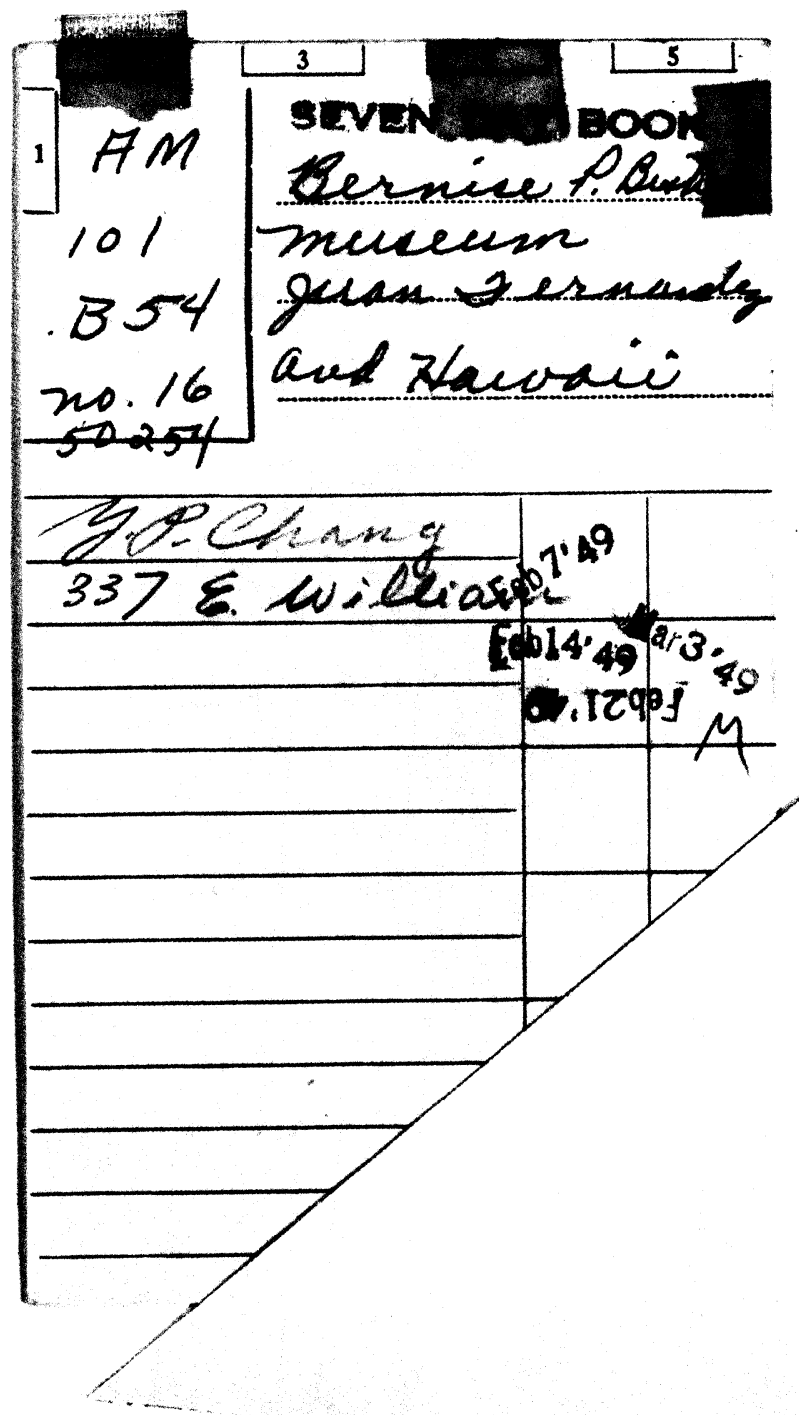


